BNL-107118-2014-IR

\title{
Inorganic Corrosion-Inhibitive Pigments for High- Temperature Alkali-activated Well Casing Foam Cement
}

\author{
Toshifumi Sugama
}

November 2014

Sustainable Energy Technologies Department

Brookhaven National Laboratory

The U.S. Department of Energy Energy Efficiency and Renewable Energy

Geothermal Technologies Program 1000 Independence Avenue SW Washington, D.C. 20585 
Notice: This manuscript has been authored by employees of Brookhaven Science Associates, LLC under Contract No. DE-AC02-98CH10886 with the U.S. Department of Energy. The publisher by accepting the manuscript for publication acknowledges that the United States Government retains a non-exclusive, paid-up, irrevocable, world-wide license to publish or reproduce the published form of this manuscript, or allow others to do so, for United States Government purposes. 


\section{DISCLAIMER}

This report was prepared as an account of work sponsored by an agency of the United States Government. Neither the United States Government nor any agency thereof, nor any of their employees, nor any of their contractors, subcontractors, or their employees, makes any warranty, express or implied, or assumes any legal liability or responsibility for the accuracy, completeness, or any third party's use or the results of such use of any information, apparatus, product, or process disclosed, or represents that its use would not infringe privately owned rights. Reference herein to any specific commercial product, process, or service by trade name, trademark, manufacturer, or otherwise, does not necessarily constitute or imply its endorsement, recommendation, or favoring by the United States Government or any agency thereof or its contractors or subcontractors. The views and opinions of authors expressed herein do not necessarily state or reflect those of the United States Government or any agency thereof. 


\title{
Inorganic Corrosion-Inhibitive Pigments for High-temperature Alkali- activated Well Casing Foam Cement
}

\author{
Prepared for \\ The U.S. Department of Energy \\ Energy Efficiency and Renewable Energy \\ Geothermal Technologies Program \\ 1000 Independence Avenue SW \\ Washington, D.C. 20585 \\ Prepared by \\ Toshifumi Sugama and Tatiana Pyatina \\ Sustainable Energy Technologies Department \\ Brookhaven National Laboratory \\ Upton, NY 11973-5000
}

November 2014

Notice: This manuscript has been authored by an employee of Brookhaven Science Associates, LLC under Contract No. DE-AC02-98CH 10886 with the U.S. Department of Energy. The publisher by accepting the manuscript for publication acknowledges that the United States Government retains a non-exclusive, paid-up, irrevocable, worldwide license to publish or reproduce the published form of this manuscript, or allow others to do so, for the United States Government purposes. 


\begin{abstract}
This study evaluates inorganic pigments for improving carbon steel (CS) brine-corrosion protection by the sodium metasilicate-activated calcium aluminate cement/Fly Ash blend at $300^{\circ} \mathrm{C}$. Calcium borosilicate (CBS) and zinc phosphate, significantly improved CS corrosion-protection by decreasing cement's permeability for corrosive ions and inhibiting anodic corrosion. An amorphous $\mathrm{Na}_{2} \mathrm{O}-\mathrm{Al}_{2} \mathrm{O}_{3}-\mathrm{SiO}_{2}-\mathrm{H}_{2} \mathrm{O}$ phase tightly attached to $\mathrm{CS}$ surface formed at $300^{\circ} \mathrm{C}$ in CBS-modified cement pore solution. The corrosion rate of the CS covered with this phase was nearly 4-fold lower than in the case of nonmodified cement pore solution where the major phase formed on the surface of CS was crystalline analcime.

Keywords: foam cement, carbon steel, polarization, anodic protection, high temperature corrosion, passive film
\end{abstract}




\section{Introduction}

Fractured, unconsolidated rock formations of geothermal wells require low-density cement slurries to avoid high hydrostatic pressures and new fractures generation during cementing job that may result in lost circulation when the cement slurry goes into the formation. One of the common and economical ways to decrease density of cement slurries is slurry foaming. The most cost-effective method to create foam cement slurry is to add a foaming agent that allows entrainment of fine air bubbles during the mixing procedure. However, a study on foam cement strongly suggested that it does not provide as good corrosion protection of carbon steel (CS) casings against brine-caused corrosion as regular, non-foamed cement [1].

To address the issue of poor corrosion protection of CS by foam cement a previous work [2] investigated the usefulness of acrylic polymer emulsion as corrosion inhibiting additive for the air-entrained foam cement system consisting of sodium metasilicate (alkali activator), calcium aluminate cement, and Class $\mathrm{F}$ fly ash (cement-forming reactants). The density of acrylic polymer-modified foam cement slurry ranged from 1.26 to $1.32 \mathrm{~g} / \mathrm{cm}^{3}$. The CS coupon coated with this cement was autoclaved at $200^{\circ}$ and $300^{\circ} \mathrm{C}$ for 24 hours before measuring the electrochemical corrosion at room temperature. Despite this short-autoclaving period, among the key factors mitigating the corrosion of CS by acrylic polymer were the good hydrothermal stability of a specific polymer structure altered in $300^{\circ} \mathrm{C}$-autoclaved cements, the reduction in the extent of infiltration and transportation of corrosive electrolytes through the cement layer deposited on the CS surface, the inhibition of the cathodic reactions at the corrosion sites of CS, the extended coverage of CS surface by cement, and the improved adherence of the cement to CS surfaces. The major role of the altered polymer was its adsorption on the surface of CS and its extensive surface coverage. However, one concern about this organic corrosion inhibitor performance at high temperature of $300^{\circ} \mathrm{C}$ was whether it would remain in effect for a long-term exposure period.

On the other hand, the inorganic corrosion-inhibitive additives, such as phosphate- and silicate-based pigments, are very attractive because of their good thermal stability and the possibility of their dry blending with cement-forming materials. Among the various phosphate-based pigments, zinc- and calcium- phosphates are widely used as environmentally benign and cost-effective pigments for replacing the toxic chromatebased corrosion inhibitors [3-7], while the silicate-based green pigments encompass calcium borosilicate and calcium- or zinc- phosphosilicates [8-10]. The pigment coating partially dissolves when in contact with aqueous solutions releasing ions that migrate to CS surface where they react with Fe oxide or hydroxide passive film and create secondary passive film, which provides additional protection against corrosion. Other identified mechanisms of creating passive film include reactions of ions released by cement and pigments into the pore solution [11-12]. A low solubility of pigments may result in insufficient ion release and poor corrosion protection; conversely, a too high solubility raises the concern over a long-term corrosion protection since the pigments may dissolve completely in a short time. Thus, for the long-term corrosion-protection by the coating, moderate solubility of the pigments is required. From this standpoint, the 
silicate-based pigments have a relatively good solubility in a high $\mathrm{pH}$ solution; conversely, a low $\mathrm{pH}$ favorably promotes the dissolution of the phosphate-based pigments.

The other inevitable factor governing the corrosion protection of CS is the chemistry of the cementitious matrix. For Ordinary Portland Cement (OPC), its alkali pore solution with $\mathrm{pH}>12$ promotes the formation of ferrous hydroxides as a passive film at the anodic corrosion reaction site of steel [13-18]. The stability of this film depends primarily on the exposure conditions. In geothermal environments, there are two major chemical factors that must be considered for triggering this film's destruction and breakdown known as the depassivation of the CS's surface and initiation of its corrosion. One factor is the prevalence of carbonate ions that cause carbonation; the other is the attack of chloride ions. The $\mathrm{Cl}^{-}$ion breaks the ferrous hydroxide-based passive film to form soluble $\mathrm{Fe}-\mathrm{Cl}$ salts, creating pitting corrosion on the surface of steel. Carbon dioxide $\left(\mathrm{CO}_{2}\right)$ can penetrate through the pores in the OPC, and then react with water to form carbonic acid, $\mathrm{H}_{2} \mathrm{CO}_{3}$, thereby lowering the $\mathrm{pH}$ of the pore solution in the OPC layers adjacent to the CS's surfaces. Such depassivation promotes the localized corrosion of CS, and subsequently, the corrosion products formed on CS's surface engender a volumetric expansion of CS, generating a stress cracking and the spallation of the OPC sheath at the boundary between the OPC and CS well casing. Further, the failure of OPC sheath at the initial stage of CS's corrosion accelerates its corrosion rate and shortens the service lifespan of the casing. Impairment of the integrity of a well structure entails the need for costly repairs and restorative operations including re-drilling the damaged well, and occasionally necessitates the assemblage of new wells. To avoid such catastrophic failure of well structure, very expensive metal components are needed, incurring a high capital investment, for example, titanium alloy, stainless steel, and inconel components, in fabricating corrosion-resistant well casings.

Unlike the OPC, the cement system employed in this study contains sodium metasilicate as an alkali activator. Several investigators [19-23] reported the corrosion mitigation effect of sodium silicate for CS. The high alkalinity of sodium silicate dissolved in an aqueous medium plays an important role in promoting the rapid deposition of a passive film on the CS. Also, the negatively charged silicate, $\mathrm{SiO}_{2}(\mathrm{OH})_{2}{ }^{-}$, released during the dissolution of sodium silicate reacts with the hydroxyl group in a pre-existing ferrous hydroxide film; $\mathrm{SiO}_{2}(\mathrm{OH})_{2}{ }^{-}+\mathrm{Fe}(\mathrm{OH})_{2} \rightarrow \mathrm{HOSiO}_{2}-\mathrm{O}-\mathrm{Fe}(\mathrm{OH})+\mathrm{H}_{2} \mathrm{O}$. This oxygenbridging silica-Fe hydroxide complex acts as an additional duplex passive layer offering a better protection than the original passive film of iron hydroxide. Thus, it is possible to assume that the sodium metasilicate in the current cement system may be effective in forming a duplex passive film as observed earlier investigators. However, silicate ions liberated from sodium metasilicate activator may be depleted quickly because of its high solubility in water and reactions with the components of the cementitious blend. Hence, incorporation of additional pigments with a moderate solubility into the calcium aluminate/Fly ash cement system may extend the corrosion-mitigating service of cements at $300^{\circ} \mathrm{C}$. 
The present study investigates the usefulness of inorganic corrosion-inhibitive pigments in improving the ability of the sodium metasilicate-activated calcium aluminate/Class $\mathrm{F}$ fly ash cement autoclaved at temperatures up to $300^{\circ} \mathrm{C}$ to mitigate the corrosion of CS in the $\mathrm{Cl}$-containing environment, but not $\mathrm{CO}_{2}$. Among the pigments, a particular focus was on calcium borosilicate that possesses good solubility in alkali solutions. Although the alkali solubility of the phosphate-based pigments is relatively poor, two phosphate-based pigments, zinc phosphate and calcium phosphate were also evaluated. Additionally, calcium nitrite $(\mathrm{CN})$, which is commonly applied to prevent $\mathrm{Cl}$-caused corrosion of steel rebar in concrete, was employed as a control. In this case, the nitrite ion, $\left(\mathrm{NO}_{2}\right)^{-}$in the calcium nitrite solution hinders the uptake of ferrous ions by $\mathrm{Cl}^{-}$from the passive film $[24,25]$.

The investigated factors encompassed the brine-caused corrosion rate of CS coated with cement after autoclaving samples at high temperature, the changes in ion conductivity through the cement and in compressive strength of cement as a function of pigment content and autoclaving temperature, and the corrosion-preventing behavior and chemistry of passive films made by immersing CS in cement pore solution with and without the pigments.

\section{Experimental Procedures}

\subsection{Materials and methods}

Three corrosion-inhibitive pigments, calcium borosilicate (CBS)-, zinc phosphate (ZP)-, and calcium phosphate (CP)-based, with the trade names "CW-292," "SZP-391," and "430," respectively, were supplied by Halox Corp. BASF supplied the calcium nitrite (CN)-based corrosion inhibitor with the trade name "Rheocrete CNI." Class F fly ash was obtained from Boral Material Technologies, Inc., and calcium aluminate cement Secar \#80 was supplied by Kerneos Inc. A sodium metasilicate granular powder under the trade name "MetsoBeads 2048," supplied by the PQ Corporation was used as the alkali activator of the fly ash. The chemical compositions of these cement-forming materials detected by micro energy-dispersive X-ray spectrometer ( $\mu$ EDX) or provided by the supplier are given in Table 1. The X-ray powder diffraction (XRD) data showed that the crystalline compounds of fly ash $\mathrm{F}$ had three major phases, quartz $\left(\mathrm{SiO}_{2}\right)$, mullite $\left(3 \mathrm{Al}_{2} \mathrm{O}_{3} \cdot 2 \mathrm{SiO}_{2}\right)$, and hematite $\left(\mathrm{Fe}_{2} \mathrm{O}_{3}\right)$, while calcium aluminate cement included three crystalline phases, corundum $\left(\alpha-\mathrm{Al}_{2} \mathrm{O}_{3}\right)$, calcium monoaluminate $\left(\mathrm{CaO} \cdot \mathrm{Al}_{2} \mathrm{O}_{3}, \mathrm{CA}\right)$, and calcium dialuminate $\left(\mathrm{CaO} .2 \mathrm{Al}_{2} \mathrm{O}_{3}, \mathrm{CA}_{2}\right)$.

The AISI 1008 cold rolled steel test panel according to ASTM D 609C was used as the carbon steel (CS) substrate, supplied by ACT Test Panels, LLC. Alkaline cleaner \#4429, supplied by American Chemical Products, was used to remove any surface contaminants of CS. This cleaner was diluted with deionized water (D.I.) to prepare a $5 \mathrm{wt} \%$ cleaning solution.

Halliburton supplied the cocamidopropyl dimethylamine oxide-based foaming agent under the trade name "ZoneSealant 2000." 
The dry blend cement formulation employed in this study was $60 \mathrm{wt} \%$ calcium aluminate cement and $40 \mathrm{wt} \%$ fly ash, class $\mathrm{F}$. The sodium silicate was added at $6.2 \%$ by total weight of the calcium aluminate/fly ash blend to prepare the one dry mix cement component. The pigments were dry blended with the cement at 3, 5, and 8 wt.\%. The $\mathrm{CN}$ corrosion-inhibiting solution was added at $5 \%$ by total weight of this dry mixture. To prepare the foam cement, 0.3-0.4\% by weight of water foaming agent was mixed with water followed by the addition of the dry blend containing the pigments. The obtained slurry was mixed in a shear-blender for $30 \mathrm{sec}$ at $2000 \mathrm{rpm}$. Such procedure made it possible to prepare aerated slurry containing a vast number of fine air bubbles. The density of the pigment-containing foam cement slurries ranged from 1.32 to $1.41 \mathrm{~g} / \mathrm{cm}^{3}$.

The surfaces of the $65 \mathrm{~mm}$ x $65 \mathrm{~mm}$ CS test panels were coated with the pigment-or CNcontaining foam cement slurry in the following sequence. First, the "as-received" test panels were immersed in a $5 \mathrm{wt} \%$ alkali-cleaning solution at $40^{\circ} \mathrm{C}$ for $10 \mathrm{~min}$; second, the surfaces of the alkali-cleaned panels were rinsed with tap water at $25^{\circ} \mathrm{C}$, and then dried for 24 hours in air at room temperature; third, the panels were dipped into a bath of cement slurries at room temperature, and withdrawn slowly; fourth, the cement slurrycovered panels were left for 3 days at room temperature, allowing the slurry to be converted into a solid layer of hydrated cement (referred to further on as "cement"); and, finally, the cement-coated panels were autoclaved for 3 days at $300^{\circ} \mathrm{C}$ before conducting the electrochemical corrosion tests at room temperature. The thickness of the cement layers deposited on the CS's surfaces ranged from $\sim 1.0$ to $\sim 1.4 \mathrm{~mm}$.

To create the passive film on the CS surfaces and evaluate the corrosion-protection of CS by this film, $1 \mathrm{~g}$ of each pigment was mixed with $35 \mathrm{~g}$ of pore solution $(\mathrm{pH} 13.3)$ extracted by centrifuging the cement slurry 20 minutes after its mixing. The suspensions of pigments in pore solution were autoclaved for 24 hours at $85^{\circ}, 200^{\circ}$, and $300^{\circ} \mathrm{C}$, under a pressure $6.89 \mathrm{MPa}$ to release the corrosion-inhibiting ionic species from the pigments. Afterward, they were filtered to remove non-dissolved pigments at room temperature. Finally, the CS was immersed into the resulting solutions for 24 hours at $85^{\circ}, 200^{\circ}$, or $300^{\circ} \mathrm{C}$ under a pressure $6.89 \mathrm{MPa}$, to create the passive film.

Table 1. Oxide composition of Thermal Shock Resistant Cement starting materials (mass percent).

\begin{tabular}{|l|c|c|c|c|c|c|c|}
\hline Component & $\mathrm{Al}_{2} \mathrm{O}_{3}$ & $\mathrm{CaO}$ & $\mathrm{SiO}_{2}$ & $\mathrm{Fe}_{2} \mathrm{O}_{3}$ & $\mathrm{Na}_{2} \mathrm{O}$ & $\mathrm{K}_{2} \mathrm{O}$ & $\mathrm{TiO}_{2}$ \\
\hline $\begin{array}{l}\text { Calcium } \\
\text { aluminate } \\
\text { cement }\end{array}$ & 73.8 & 26.1 & - & 0.1 & - & - & - \\
\hline $\begin{array}{l}\text { Flay ash } \\
\text { class F }\end{array}$ & 34.8 & 2.7 & 50.4 & 7.1 & 0.3 & 3.1 & 1.6 \\
\hline $\begin{array}{l}\text { Sodium } \\
\text { meta } \\
\text { silicate }\end{array}$ & - & - & 46.6 & - & 50.5 & - & - \\
\hline
\end{tabular}




\subsection{Measurements}

The density, $\mathrm{g} / \mathrm{cm}^{3}$, of the foam cement slurries was determined using the fluid density container. Then, the slurries were poured in cylindrical molds $(20 \mathrm{~mm}$ diam. and $40 \mathrm{~mm}$ long) and left for 3 days at room temperature to cure. Thereafter, the hardened foam cements were removed from the molds and autoclaved at $300^{\circ} \mathrm{C}$ for 3 days, then left for 24 hours at room temperature. The changes in compressive strength of the $300^{\circ} \mathrm{C}-3 \mathrm{day}-$ autoclaved cements as a function of pigment's content were obtained using Electromechanical Instron Model 5967. The morphology, elemental composition, and chemical states of the passive films formed on CS were identified using High-Resolution Scanning Electron Microscopy (HR-SEM), Energy-dispersive X-ray Spectrometer (EDX), and X-ray powder diffraction (XRD) using $\mathrm{Cu} \mathrm{K} \alpha$ radiation (40 kV, $40 \mathrm{~mA}$ ). DC electrochemical testing for corrosion of the underlying CS was performed with the EG\&G Princeton Applied Research Model 326-1 Corrosion Measurement System. In this assessment, the cement-coated CS specimen was mounted in a holder, and then inserted into an EG\&G Model K47 electrochemical cell containing a 1.0 M sodium chloride electrolyte solution. The test was conducted under aerated conditions at $25^{\circ} \mathrm{C}$, on an exposed surface area of $1.0 \mathrm{~cm}^{2}$. The polarization curves were measured at a scan rate of $0.5 \mathrm{mVs}^{-1}$ in the corrosion potential range from -0.05 to $-0.75 \mathrm{~V}$. AC electrochemical impedance spectroscopy (EIS) was used to evaluate the ability of the cement layers to protect the CS from corrosion. The coated CS specimens with a surface area of $1.0 \mathrm{~cm}^{2}$ were mounted in a holder, and then inserted into an electrochemical cell containing a 1.0 $\mathrm{M}$ sodium chloride electrolyte at $25^{\circ} \mathrm{C}$, and single-sine technology with an input AC voltage of $10 \mathrm{mV}$ was employed over a frequency range of $10^{5}$ to $10^{-3} \mathrm{~Hz}$. To estimate the protective performance of the cements, the pore resistance, $R_{p}$, $\left(\mathrm{ohm}-\mathrm{cm}^{2}\right)$ was determined from the plateau in the low frequency regions of Bode-plot scans.

\begin{tabular}{|llll|}
\hline \multicolumn{2}{|l}{ Abbreviations } & & \\
CS & Carbon Steel & PS & Pore solution \\
OPC & Ordinary Portland Cement & HR-SEM & High - Resolution Scanning Electron Microscopy \\
CBS & Calcium Borosilicate & EDX & Energy Dispersive X-ray Spectrometry \\
ZP & Zinc Phosphate & XRD & X-ray powder Diffraction \\
CP & Calcium Phosphate & EIS & Electrochemical Impedance Spectroscopy \\
CN & Calcium Nitrite & $R_{p}$ & Pore resistance \\
D.I. & deionized & $E_{c o r r}$ & Corrosion Potential \\
\hline
\end{tabular}

\section{Results and discussion}

\subsection{Pigment-containing cement coatings}

To evaluate the potential of inorganic pigments for mitigating the corrosion of CS, the two electrochemical corrosion studies were conducted. The first study centered on surveying the effect of pigments and $\mathrm{CN}$ on reducing the brine-caused corrosion rate of $\mathrm{CS}$; the second one was to investigate the ability of pigments to minimize the infiltration and transportation of a corrosive electrolyte through the foam cement layer covering the CS surfaces. 
Figure 1 illustrates the cathodic-anodic polarization curves of the potential voltage, V, versus current, A, at room temperature, for CS coupons covered with the $300^{\circ} \mathrm{C}$ autoclaved foam cements with and without $5 \mathrm{wt} \%$ pigments and $\mathrm{CN}$. The shapes of the curves reveal the transition from cathodic polarization region at the onset of the most negative potential to the anodic polarization region at the less negative potential. The value of the potential at the transition point from cathodic to anodic regions is the corrosion potential, $E_{\text {corr }}$. There were two noticeable differences between the curves of the CS coated with the corrosion inhibitor-free foam cement (control) and that coated with pigment-containing cements. One was a shift in the $E_{\text {corr }}$ to less negative values for all modified cements with the exception of $\mathrm{CN}$ inhibitor-containing one; the other was the shift of the anodic part of the curves to the lower values of current density. The first difference directly reflects the extent of coverage of the cement over the CS surface; namely, a good coverage by a continuous void-free coating layer at the contact zones with CS surface is responsible for moving the $E_{c o r r}$ value to a more positive potential in the presence of these pigments. For the second difference, the decline of anodic current signified the inhibition of anodic reaction at the corrosion sites of CS by the pigments that created a protective film on the surface of CS.

Among these pigments, CBS was the most effective as an anodic inhibitor for this cement system. In contrast, $\mathrm{CN}$ was not effective in improving the corrosion mitigation by cement, reflecting neither an enhanced coverage of cement nor the formation of advanced passive film. No further study was undertaken on $\mathrm{CN}$.

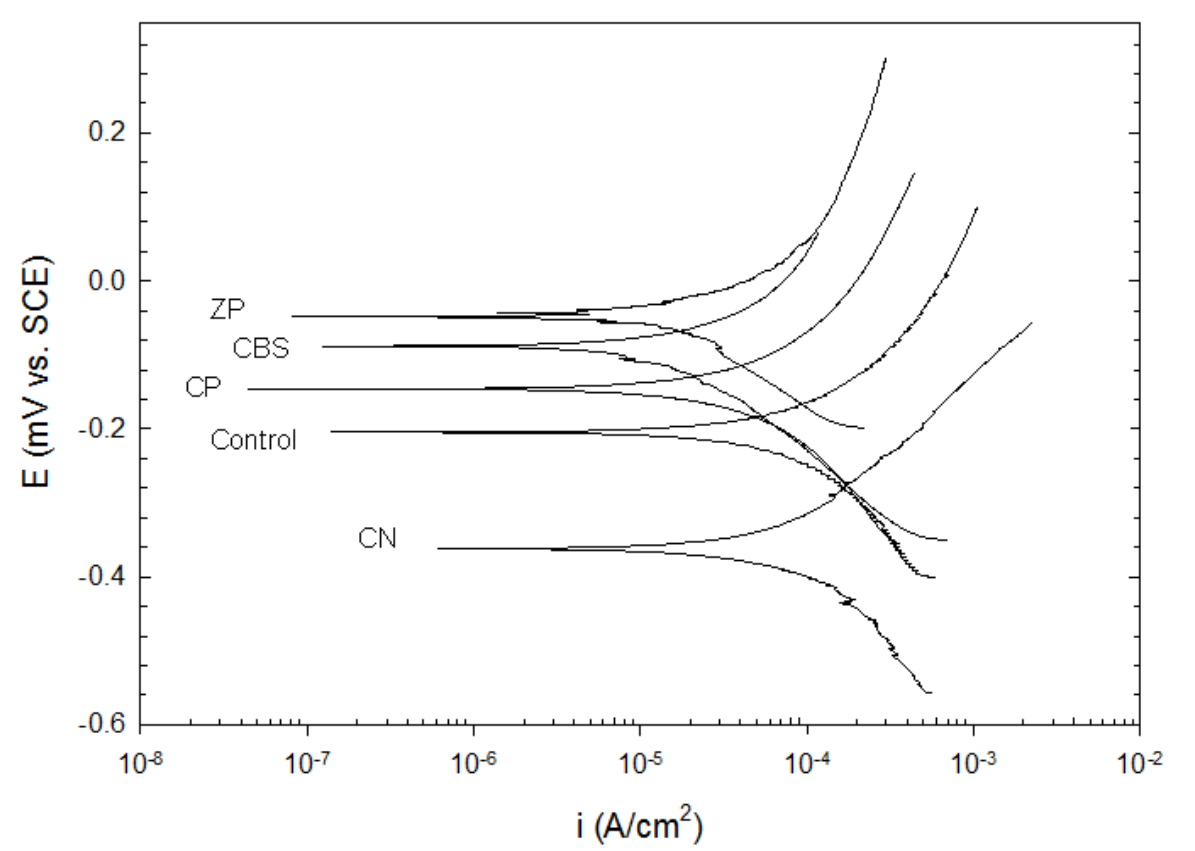

Figure 1. Potentiodynamic polarization diagrams for CS coated with $\mathrm{CN}, \mathrm{CP}, \mathrm{CBS}$, and $\mathrm{ZP}$-containing foam cements after autoclaving at $300^{\circ} \mathrm{C}$.

The corrosion rate of CS covered with the cements with and without pigments and CN was computed from Tafel analyses of these potentiodynamic polarization curves (Table 
2). For the control, the corrosion rate was $7.1 \mu \mathrm{m} /$ day with $I_{\text {corr }}$ of $227.71 \mu \mathrm{A} / \mathrm{cm}^{2}$. These values dropped to 5.2 and $164.61 \mu \mathrm{A} / \mathrm{cm}^{2}$ when cement was modified with $5 \mathrm{wt} \% \mathrm{CP}$. A striking reduction of these values was observed in the presence of $\mathrm{ZP}$ and CBS pigments. The corrosion rate of 1.5 and $1.4 \mu \mathrm{m} /$ day for ZP and CBS was tantamount to nearly 5fold decrease in comparison with that of the control, demonstrating the effectiveness of these pigments in impeding the brine-caused corrosion of CS and in aiding the assemblage of protective passive film at the anodic reaction site. The $\mathrm{CN}$ inhibitor did not provide any reduction of corrosion rate of CS in the $300^{\circ} \mathrm{C}$-autoclaved cement system.

Table 2. Tafel analysis for carbon steel (CS) covered with various pigment- and CNcontaining foam cements after autoclaving at $300^{\circ} \mathrm{C}$.

\begin{tabular}{|l|c|c|c|}
\hline Inhibitor & $\boldsymbol{E}_{\text {corr }}(\mathbf{I}=\boldsymbol{0}),(\mathbf{m V})$ & $\boldsymbol{I}_{\text {corr, }}\left(\boldsymbol{\mu} \mathbf{\mathrm { A } / \mathbf { c m } ^ { 2 } )}\right.$ & Corrosion rate, $(\boldsymbol{\mu m} / \mathbf{d a y})$ \\
\hline Control & -204.62 & 227.71 & 7.1 \\
\hline CN & -362.03 & 254.86 & 8.2 \\
\hline CP & -144.39 & 164.61 & 5.2 \\
\hline CBS & -88.69 & 45.16 & 1.4 \\
\hline ZP & -48.45 & 47.49 & 1.5 \\
\hline
\end{tabular}

Figure 2 shows the changes in corrosion rate of CS coated with the $300^{\circ} \mathrm{C}$-autclaved $\mathrm{CP}$-, $\mathrm{ZP}-$, and CBS-modified cements as a function of pigment content. For all these pigments, the corrosion rate of CS declined when their content increases up to $5 \mathrm{wt} \%$, beyond that, it leveled off. Thus, the efficiency of cement in inhibiting CS's corrosion depends on the amount of pigments; with the content of $\geq 5 \mathrm{wt} \%$ assuring adequate protection under the experimental conditions.

Other major parameter governing the mitigation of corrosion by the cements is their conductivity of corrosive electrolytes. The extent of electrolytes uptake by the cements plays a pivotal role in inhibiting or accelerating the corrosion of the underlying CS. The extent of conductivity and transportation of $\mathrm{NaCl}$ ionic electrolytes through the cement layer deposited to the underlying CS surfaces was determined using EIS.

Figure 3 compares the Bode-plots [the absolute value of impedance $|\mathrm{Z}|\left(\Omega-\mathrm{cm}^{2}\right)$ vs. frequency $(\mathrm{Hz})]$ of the $\mathrm{CS}$ coupons coated with the pigment-free or $5 \mathrm{wt} \% \mathrm{CP}-, \mathrm{ZP}-$, and CBS pigment-modified foam cements after autoclaving at $300^{\circ} \mathrm{C}$. 


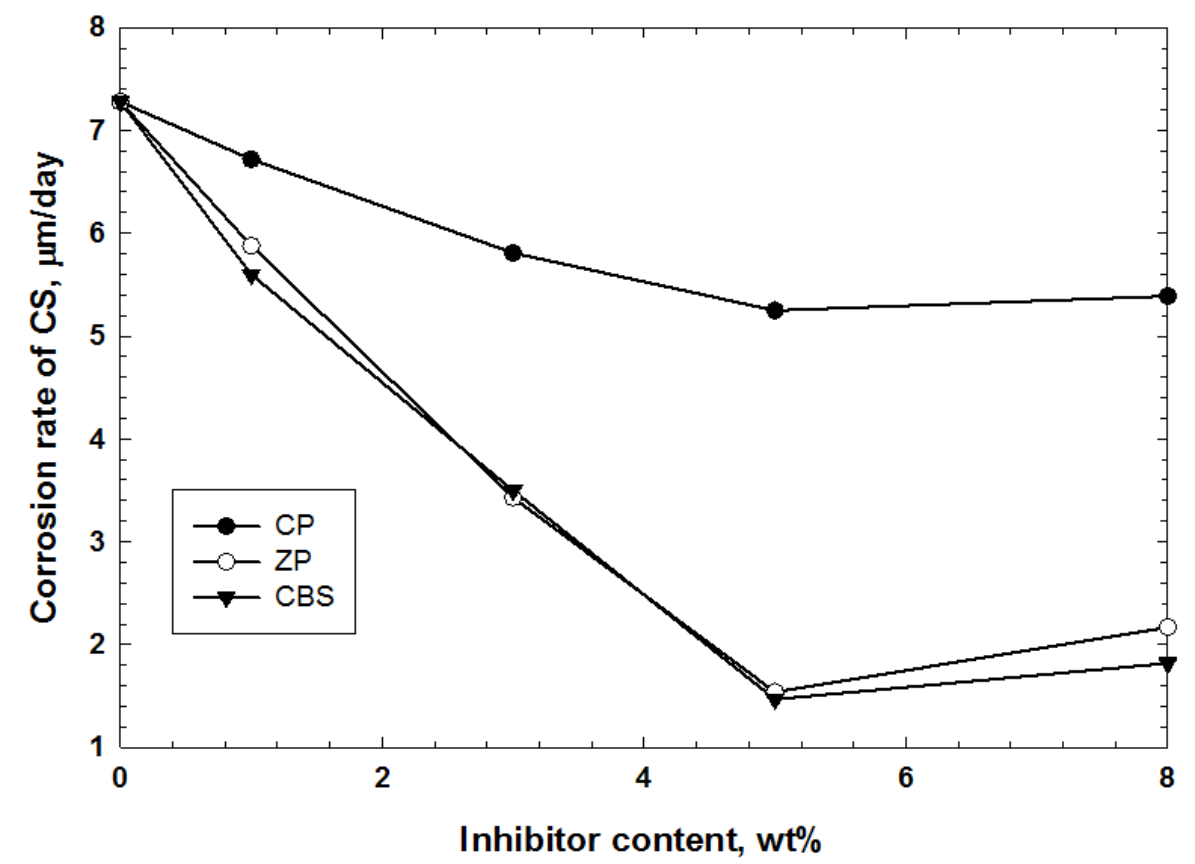

Figure 2. Changes in corrosion rate of CS as a function of pigments content.

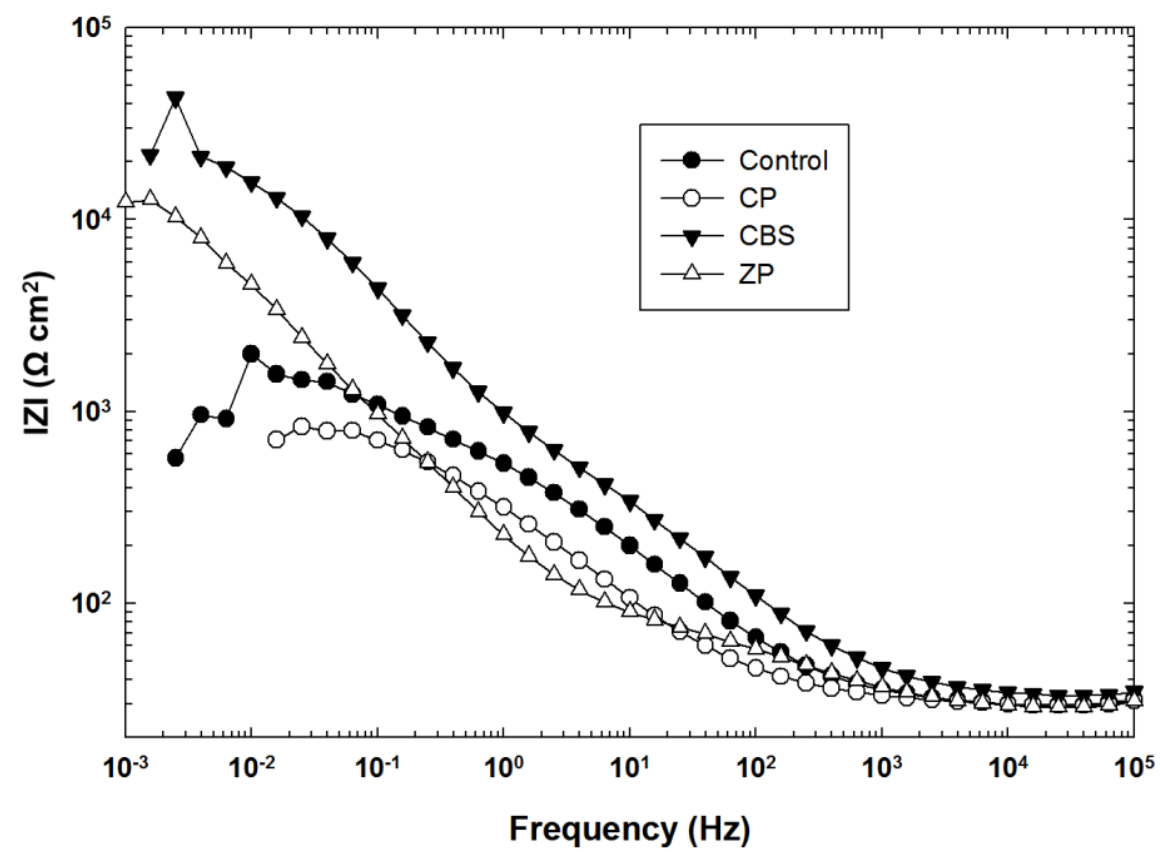

Figure 3. AC electrochemical impedance curves for the CS coated with the control and 5 $\mathrm{wt} \%$ pigment-modified foam cements after autoclaving at $300^{\circ} \mathrm{C}$. 
The EIS curves were used to evaluate the pore resistance, $R_{p}$, which can be determined from the peak in the Bode-plot occurring at a low frequency between $10^{-1}$ and $10^{-2} \mathrm{~Hz}$. For the pigment-free cement coating control sample, the $R_{p}$ value was $1.99 \mathrm{k} \Omega-\mathrm{cm}^{2}$. It increased by nearly 6.2 -fold and 10.6 -fold to a 12.30 and $21.17 \mathrm{k} \Omega-\mathrm{cm}^{2}$, when this coating was modified with ZP and CBS pigments, respectively. Since the $R_{p}$ value reflects the extent of ionic conductivity by the $\mathrm{NaCl}$ electrolyte passing through the coating layer, such an enhanced pore resistance represents a decrease in the uptake of electrolytes by the coating. In other words, the ZP- and CBS-containing foam coatings displayed better resistance to the infiltration and transportation of electrolyte through cement layer than did the pigment-free coating, suggesting that these pigments served to densify the structure of foam cement during autoclaving at $300^{\circ} \mathrm{C}$. In contrast, $\mathrm{CP}$ was not as effective in densifying the cement as ZP and CBS; in fact, the $R_{p}$ value for CPmodified cement was somewhat lower than that of the pigment-free cement.

Figure 4 depicts the changes in $R_{p}$ value, of $300^{\circ} \mathrm{C}$-autoclaved foam cements as a function of pigment content. For ZP and CBS, this value conspicuously rose between the contents of 3 and $5 \mathrm{wt} \%$, beyond that, it monotonously increased between 5 and $8 \mathrm{wt} \%$.

Meanwhile, adding CP negatively affected the pore resistance. This data also revealed that the effect of CBS on the cement structure was greater than that of ZP. As described in the previous polarization tests, the surface of CS was covered extensively with the CBS- and ZP-modified cements. The increased pore resistance may be correlated with the densified cement structure in the presence of these pigments resulting in the lower number of pores at the cement-CS interface.

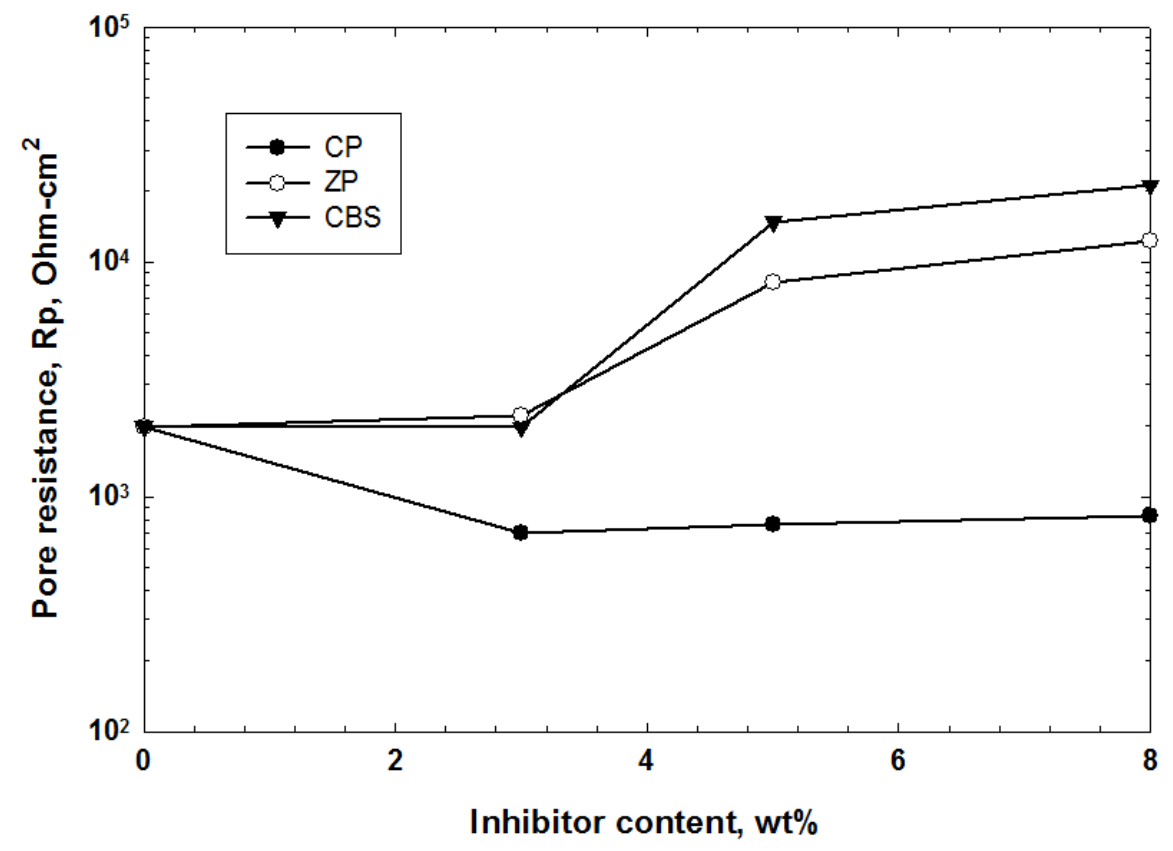

Figure 4. Changes in pore resistance as a function of pigment content. 
To verify if pigment-modified cement had a denser structure the changes in compressive strength of $300^{\circ} \mathrm{C}$-autocalved foam cements as a function of pigment content were determined (Figure 5). The ZP- and CBS-containing cements revealed a rise of compressive strength with an increasing content of the pigments, strongly suggesting that these pigments densified the structure of foam cements during the autoclaving at $300^{\circ} \mathrm{C}$. The $8 \mathrm{wt} \% \mathrm{ZP}$ - and CBS-filled foam cements had a compressive strength of 11.6 and 16.1 MPa, respectively, which were tantamount to 2.2- and 3.0-fold increase, compared with that of the pigment-free one. In contrast, adding $\mathrm{CP}$ at various concentrations did not show any noticeable changes in compressive strength.

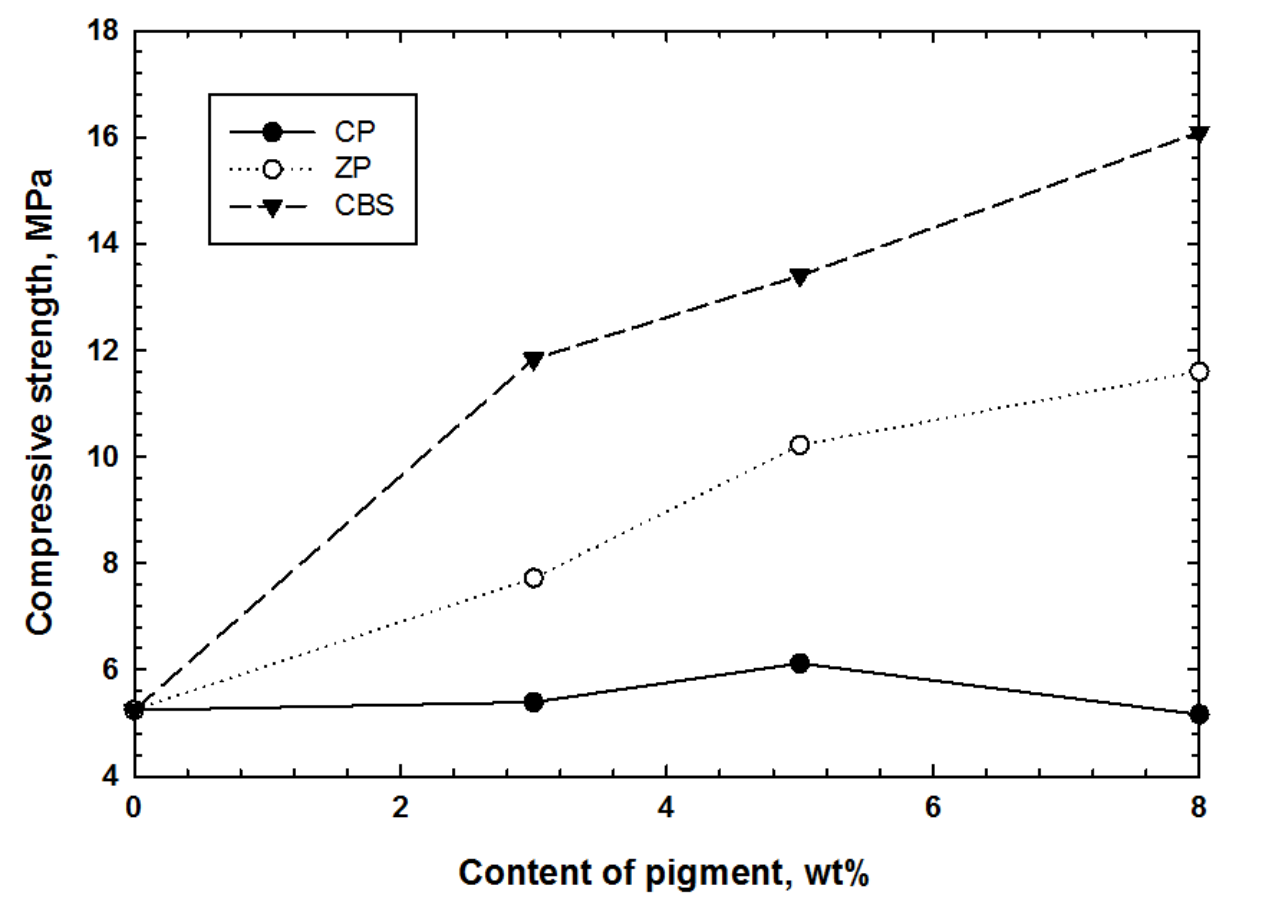

Figure 5. Compressive strength vs. pigment content for $300^{\circ} \mathrm{C}$-autoclaved foam cements.

\subsection{Passive films formed hydrothermally at $300^{\circ} \mathrm{C}$}

These results suggested that the corrosion-inhibitive pigment suitable for foam cement was required to possess two important properties: an ability to fabricate a protective passive film on the CS's surfaces and to densify the structure of foam cement. The next focus was on assessing the ability of the pigments to fabricate a protective passive film on CS surfaces.

Under hydrothermal conditions at $300^{\circ} \mathrm{C}$ the surface of CS coated with sodium metasilicate-activated cement slurry modified with a pigment is in contact with the pore solution (PS) that contains reactive ionic species coming from two sources. One is the dissolution of the pigment in the cement slurry; the other is the cement slurry itself. Assuming this concept is valid, corrosion rates of CS treated at $300^{\circ} \mathrm{C}$ with PSs 
containing studied pigments were evaluated. Simulated pore solutions are commonly used in studies of steel corrosion in concrete [26-29]. For the present study the actual PS of $\mathrm{pH} 13.3$ was extracted from cement slurry and used to dissolve a certain amount of pigments. The pigments were mixed with the PS and autoclaved at $300^{\circ} \mathrm{C}$ under a pressure of $6.89 \mathrm{MPa}$ for 24 hours. The autoclaved PS was filtered through paper filter to eliminate all undissolved pigments, and then the CS was immersed into the obtained filtrate and autoclaved at $300^{\circ} \mathrm{C}$ under a pressure of $6.89 \mathrm{MPa}$ for 24 hours. Finally, the surface of CS was cleaned with D.I. water-soaked cotton tissue at room temperature to remove any non-adhering precipitates.

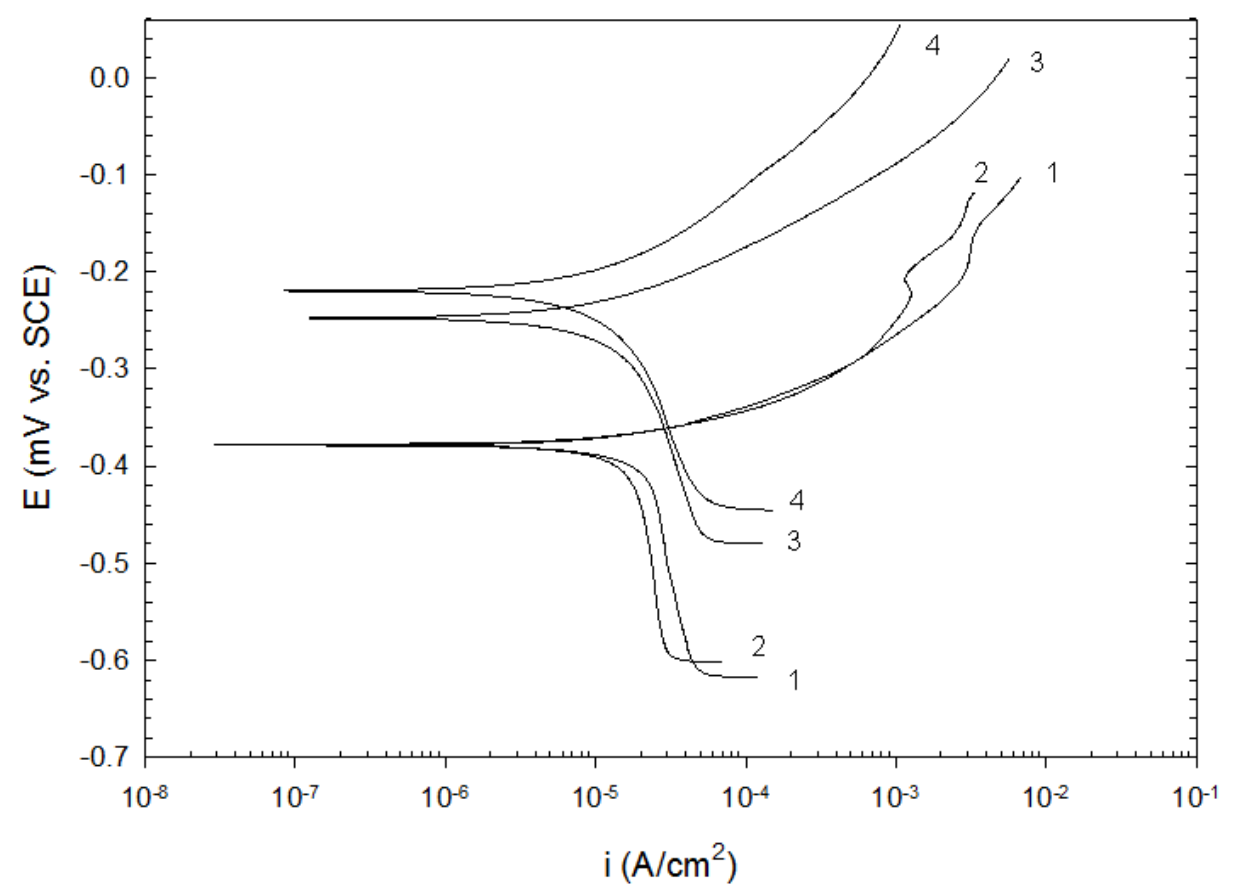

Figure 6. Potentiodynamic polarization diagrams for non-treated CS (1) and CS treated with $\mathrm{PS}$ at $85^{\circ}(2), 200^{\circ}(3)$, and $300^{\circ} \mathrm{C}(4)$.

To understand the role of pigments in improving the original passive film present on the CS's surfaces, the efficacy of the PS without pigments in improving the corrosion mitigation of the original passive film was evaluated first. Figure 6 shows the potentiodynamic polarization curves for the CS treated with PS at $85^{\circ}, 200^{\circ}$, and $300^{\circ} \mathrm{C}$. As is evident from the comparison of curve's features, there were no significant differences between the curves of CS with the PS treatment at $85^{\circ} \mathrm{C}$ and the "as-received" $\mathrm{CS}$ denoted as non-treated. In contrast, increasing the temperature to $200^{\circ} \mathrm{C}$ resulted in the increase of the $E_{c o r r}$ value and the shift of the anodic part of the curve to lower anodic current density values, highlighting that the PS at this temperature enhanced the extent of the coverage by protective passive film over the CS's surface (higher $\mathrm{E}_{\text {corr }}$ ), and this film offered an improved anodic corrosion protection (decreased anodic current density). Further increase in the $E_{\text {corr }}$ value and decrease in the anodic current density was observed for the $300^{\circ} \mathrm{C}$ PS-treated CS. Meanwhile, there was no conspicuous change in 
the cathodic current at the beginning of the curve. Thus, it appeared that the PS at $200^{\circ}$ and $300^{\circ} \mathrm{C}$ was more likely to confer the anodic corrosion protection on the $\mathrm{CS}$, than the cathodic protection. Additionally, this protection was better for $300^{\circ} \mathrm{C}$-autoclaved PS than for $200^{\circ} \mathrm{C}$-autoclaved one. Table 3 summarizes the results of Tafel calculation for these curves. Undoubtedly, the corrosion rate of CS tended to reduce with the increasing treatment temperature.

Table 3. Tafel analysis for control, and cement pore solution (PS)-treated carbon steel (CS) at $85^{\circ}, 200^{\circ}$, and $300^{\circ} \mathrm{C}$.

\begin{tabular}{|c|c|c|c|}
\hline Temperature of PS, ${ }^{\circ} \mathbf{C}$ & $E_{\text {corr }}(\mathbf{I}=\mathbf{0}),(\mathbf{m V})$ & $I_{\text {corr }},\left(\mu \mathbf{A} / \mathbf{c m}^{2}\right)$ & Corrosion rate, $(\boldsymbol{\mu m} / \mathbf{d a y})$ \\
\hline Non-treated CS & -378.53 & 22.78 & 0.71 \\
\hline 85 & -377.85 & 21.60 & 0.69 \\
\hline 200 & -247.40 & 18.01 & 0.57 \\
\hline 300 & -219.55 & 17.62 & 0.56 \\
\hline
\end{tabular}

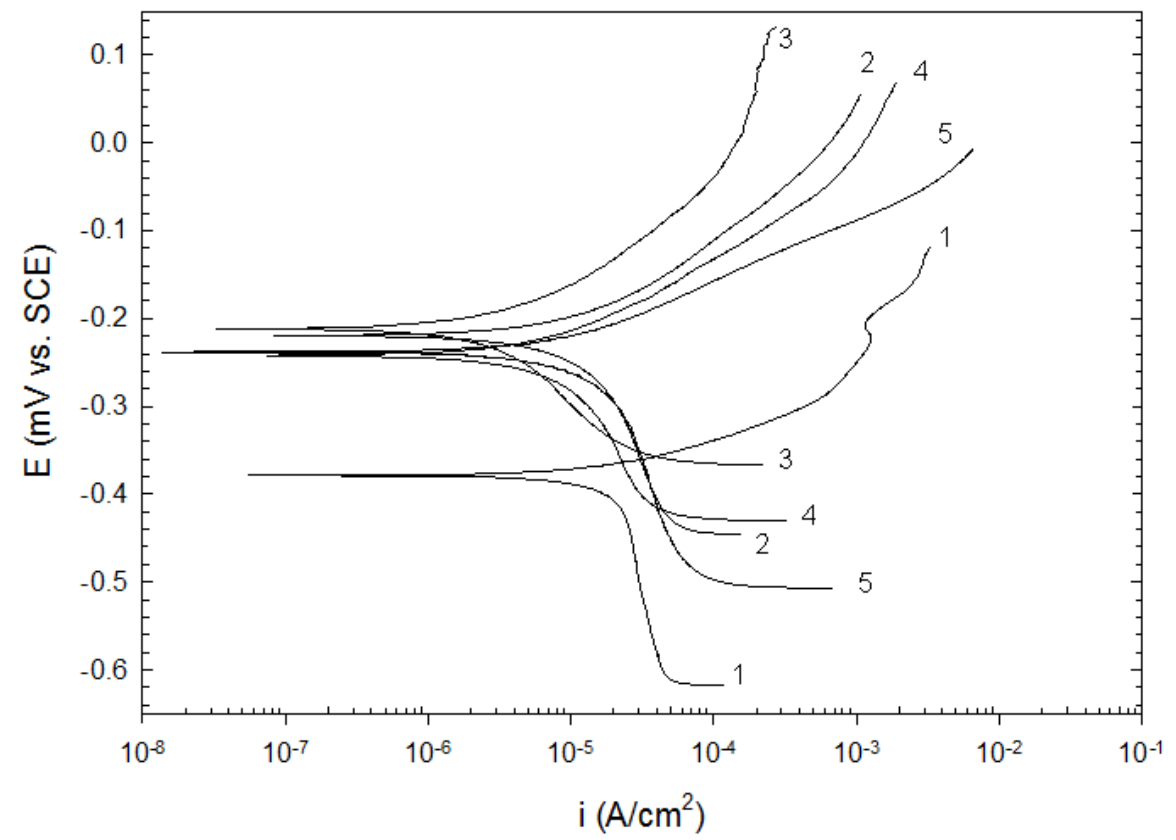

Figure 7. Potentiodynamic polarization diagrams for non-treated CS (1), and CS treated with PS containing no pigment (2), CBS (3), ZP (4), and $\mathrm{CP}(5)$ pigments at $300^{\circ} \mathrm{C}$. 
The role of pigments in further improving the corrosion mitigation of CS was studied next. Figure 7 depicts the potentiodynamic polarization curves for the CS treated with the PSs containing ionic reactants extracted from various pigments at $300^{\circ} \mathrm{C}$. Similar to the study with pore solution without the pigments the two aspects monitored for evaluating the effectiveness of pigments in further improving the corrosion protection were the $E_{c o r r}$ and the anodic current density. Among the tested pigments, CBS displayed the most promising curve's features. It had the highest $E_{\text {corr }}$ value and the lowest anodic current densities. Consequently, the CS treated with CBS-modified PS revealed the lowest corrosion rate of $0.14 \mu \mathrm{m} / \mathrm{day}$, which is equal to an improvement of 4.2-, 4.1-, and 2,5fold, respectively, in the efficiency of corrosion mitigation, compared with that of the PS alone, and CP- and ZP-modified PSs (Table 4).

Table 4. Tafel analysis for control and carbon steel (CS) treated with cement pore solution (PS) containing various pigments at $300^{\circ} \mathrm{C}$.

\begin{tabular}{|c|c|c|c|}
\hline Extracted reactant & $E_{\text {corr }}(\boldsymbol{I}=\mathbf{0}),(\mathbf{m V})$ & $I_{\text {corr }},\left(\mu \mathrm{A} / \mathbf{c m}^{2}\right)$ & Corrosion rate, $(\mu \mathrm{m} /$ day $)$ \\
\hline Non-treated CS & -378.53 & 22.78 & 0.71 \\
\hline PS & -219.55 & 17.62 & 0.55 \\
\hline PS + CBS & -211.62 & 4.15 & 0.14 \\
\hline PS + ZP & -241.83 & 10.55 & 0.33 \\
\hline PS + CP & -238.28 & 16.99 & 0.55 \\
\hline
\end{tabular}

Figure 8 plots the corrosion rate of CS treated with various pigment-modified and nonmodified pore solutions at $85^{\circ}, 200^{\circ}$, and $300^{\circ} \mathrm{C}$. The data revealed that for all pigmentmodified pore solutions, the corrosion rate showed the downward trend to a lower value as the hydrothermal temperature increased to $300^{\circ}$ from $85^{\circ} \mathrm{C}$. The highest reduction of this rate was obtained from CBS. Namely, a $0.14 \mu \mathrm{m}$ per day at $300^{\circ} \mathrm{C}$ corresponded to the reduction of $71 \%$ from a $0.46 \mu \mathrm{m}$ per day at $85^{\circ} \mathrm{C}$. Thus, among the tested pigments, CBS appeared to be the most effective in creating a passive film and in further improving the PS-derived passivation of the CS at high hydrothermal temperature.

The surfaces of CS treated at $300^{\circ} \mathrm{C}$ with PS containing tested pigments were explored by HR-SEM coupled with EDX and XRD. For comparison two control samples were tested: One was the CS after exposure to $300^{\circ} \mathrm{C}$ for 24 hours in D.I. water; the other was the passive film obtained after CS autoclaving in PS at $300^{\circ} \mathrm{C}$. The surface of D.I. watertreated CS disclosed a typical localized pitting corrosion with numerous small cavities in CS. In contrast, the PS-treated surface was covered by a very rough passive film. 
This rough surface was transformed into a dense smooth one by adding CBS to PS, showing that the functional ionic species released by CBS aided in achieving the rough $\rightarrow$ smooth alteration of the passive film.

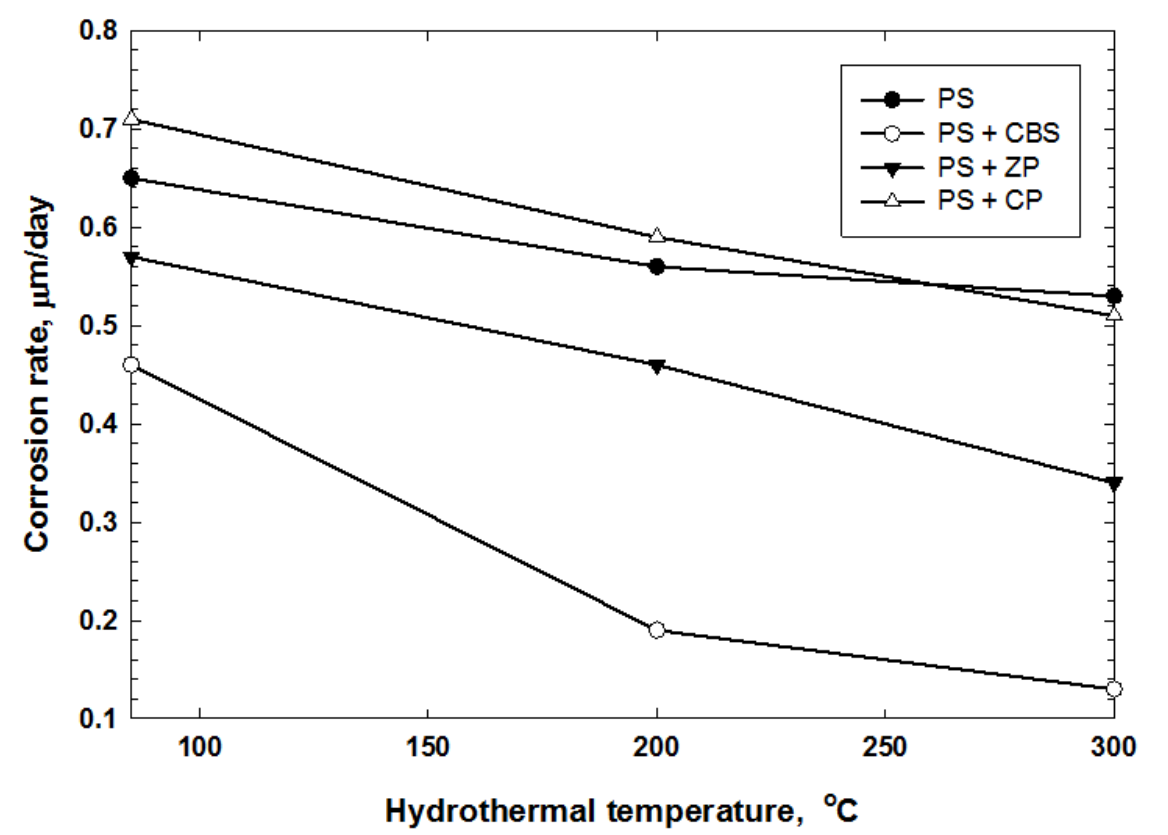

Figure 8. Changes in corrosion rate of CS treated with PS containing no pigment or CBS, $\mathrm{ZP}$, and $\mathrm{CP}$ pigments as a function of hydrothermal temperature.

Figure 9 shows the magnified HR-SEM images of PS-treated CS surface. The image revealed the development of two different morphologies. One was the clusters of cubic crystals of $\sim 20 \mu \mathrm{m}$ diam.; the other was the reticulate conformation in direct contact with CS surface. For the cubic crystals, the composition in the area A identified by EDX elemental analysis (in atomic percent) was $65 \% \mathrm{O}, 6.3 \% \mathrm{Na}, 7.2 \% \mathrm{Al}, 18 \% \mathrm{Si}, 0.16 \%$ $\mathrm{Ca}$, and $0.20 \% \mathrm{Fe}$. All these elements, except for Fe and some O, came from PS extracted from cement slurry, with $\mathrm{Si}$ as the major element, and $\mathrm{Na}$ and $\mathrm{Al}$ as minor ones, while $\mathrm{Ca}$ content was very low. Furthermore, the $\mathrm{Na}$ to $\mathrm{Al}$ ratio was 0.9 . The same $\mathrm{Na}$ to $\mathrm{Al}$ ratio was measured for the reticulate-shaped reaction products, while Si was the principal element with the atomic fraction of $13 \%$. Thus, although the PS-derived passive film was composed of two differently-shaped reaction products, they had a similar chemical composition. Figure 10 shows the HR-SEM high magnification image coupled with EDX analysis for PS/CBS-derived passive film. Of particular interest was a peculiar conformation of passive film that formed in close proximity to the CS surface. First, no clusters formed; the surface texture was relatively smooth; second was a reticulateshaped reaction products similar to those observed from PS-derived film; and third was a random distribution of cotton ball-like reaction products linked to the reticulate-shaped reaction products. The image showed that the reaction products forming the passive film adhered well to the CS surface. EDX data for both second and third conformations exhibited the similar atomic ratios of $\mathrm{Na}$ to $\mathrm{Al}$ to $\mathrm{Si}$, suggesting a chemically 
homogenous product. Furthermore, the $\mathrm{Na} / \mathrm{Si}$ and $\mathrm{Al} / \mathrm{Si}$ ratios for reticulate product derived from PS/CBS were 0.12 and 0.16 , respectively, which closely resembled that of the PS-derived reticulate product. Thus, the same reaction product containing $\mathrm{Si}, \mathrm{Na}$, and Al elements was formed in both PS- and PS/CBS-derived passive films.

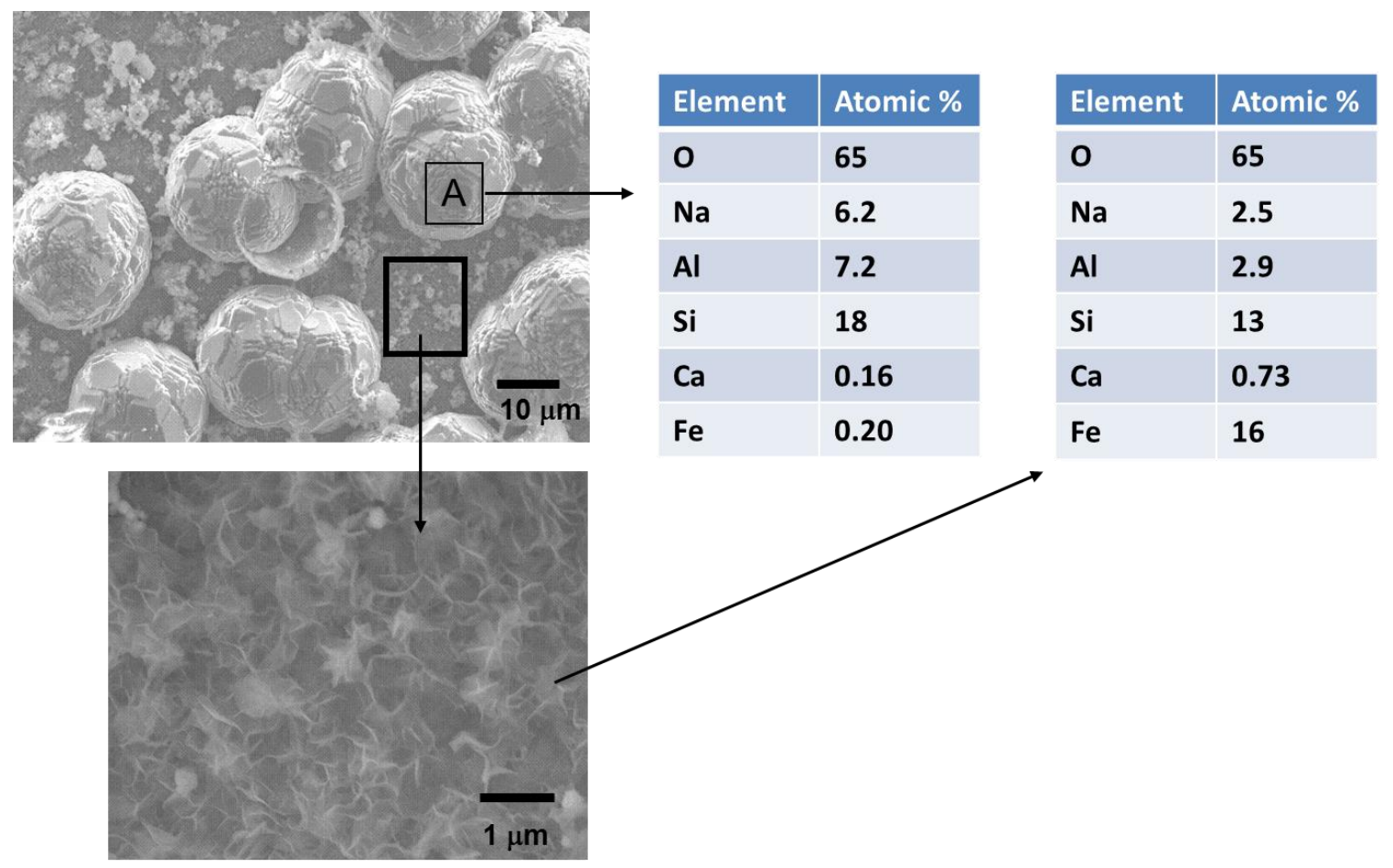

Figure 9. HR-SEM images coupled with EDX elemental analysis for PS-treated CS surface at $300^{\circ} \mathrm{C}$.

Since the EDX X-ray penetration depth is $\sim 2 \mu \mathrm{m}$, the comparison between Fe contents in the passive films would provide the information on their thickness; namely, the higher the content of Fe from the underlying CS the thinner is the film. Although both passive films disclosed a similar film conformation, their thickness differed. The Fe content (in atomic percent) of reticulate-shaped film derived from PS alone was $16 \%$, which was $\sim 61 \%$ lower than that from PS/CBS, demonstrating that the reticulate passive film from PS/CBS was considerably thinner than that from PS. It should be noted that there was no boron deteted in the PS/CBS-derived film. Thus, although CBS was dissolved in PS, a liberated $B$ ion was not included into this film (or included in very low concentrations). The image of PS/CP-derived film (Figure 11) revealed the presence of cubic crystals marked as area A. This oxide crystal was mainly assembled from $\mathrm{Na}, \mathrm{Al}$, and $\mathrm{Si}$, and the atomic proportion of $\mathrm{Na}$ to $\mathrm{Al}$ to $\mathrm{Si}$ was very similar to that derived from PS alone. Also, the image disclosed another reaction product with wrinkle-like morphology in the area B. EDX analysis showed the following atomic percentage for the four major elements $65 \%$ $\mathrm{O}, 19 \% \mathrm{Fe}, 6.3 \% \mathrm{Al}$, and $9.4 \% \mathrm{Si}$, with $0.14 \% \mathrm{Na}$ as the minor component, suggesting that this wrinkle-shaped reaction product essentially differed from the reticulate-shaped one formed on PS alone- and PS/CBS -treated CS surfaces. Additionally, there was no P from $\mathrm{CP}$ detected in this film. 


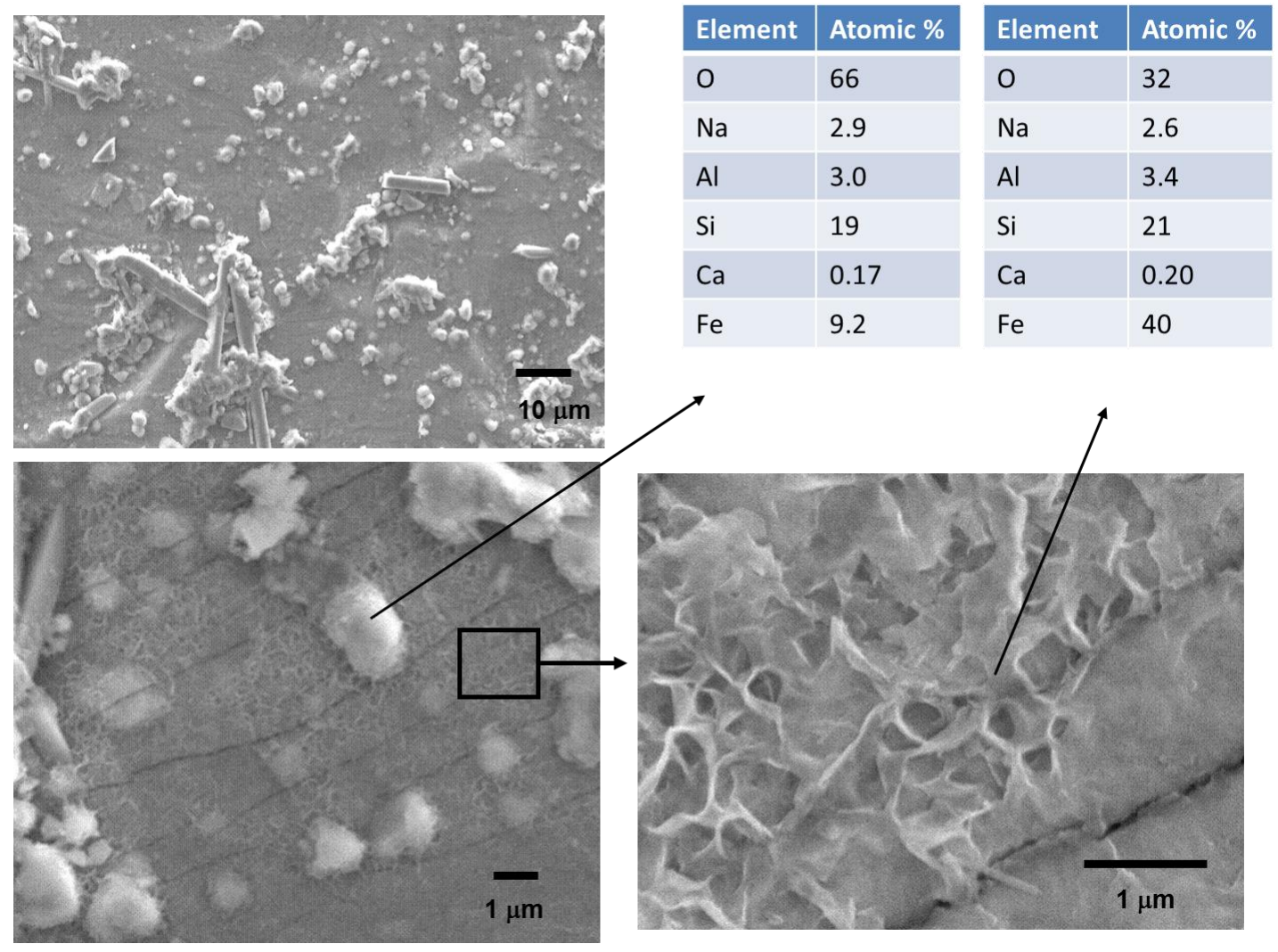

Figure 10. HR-SEM images coupled with EDX elemental analysis for PS/CBS-treated CS surface at $300^{\circ} \mathrm{C}$.

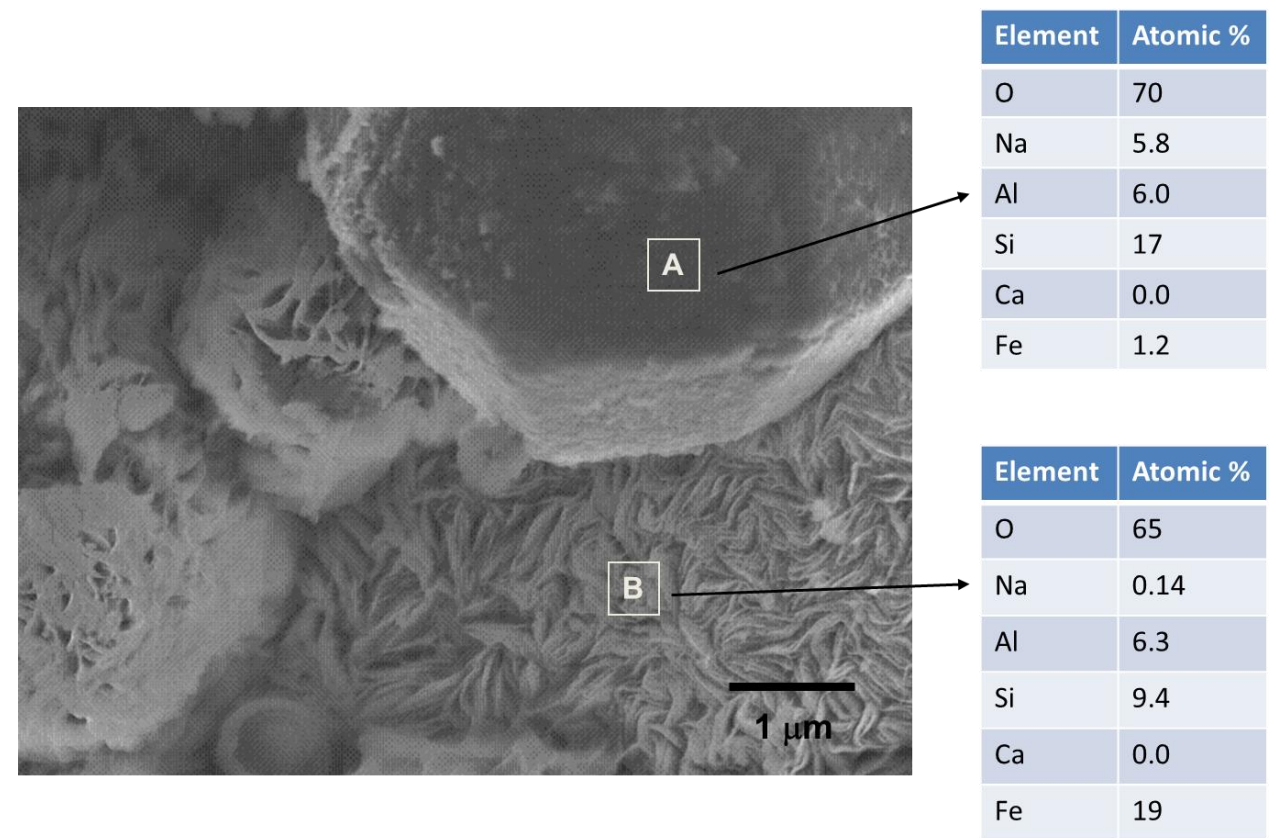

Figure 11. HR-SEM image coupled with EDX elemental analysis for PS/CP-treated CS surface at $300^{\circ} \mathrm{C}$. 
Figure 12 shows the microstructure of PS/ZP-derived passive film with two distinctive morphologies. One was smooth in the area A; the other was porous, dendritic in the area B. As is evident from EDX data concomitant to these images, the atomic compositions were similar in both areas, suggesting chemically homogeneous reaction product. This oxide film contained three major elements, $\mathrm{O}, \mathrm{Al}$ and $\mathrm{Si}$, and one minor element, $\mathrm{Na}$, and it was less thick than the PS- and PS/CP-derived films because of the high Fe content of more than 30 atomic $\%$. Additionally, no cubic crystalline reaction product was formed in the PS/ZP-derived film, nor did EDX spectrum from this film showed $\mathrm{P}$ or $\mathrm{Zn}$ elements related to ZP pigment.

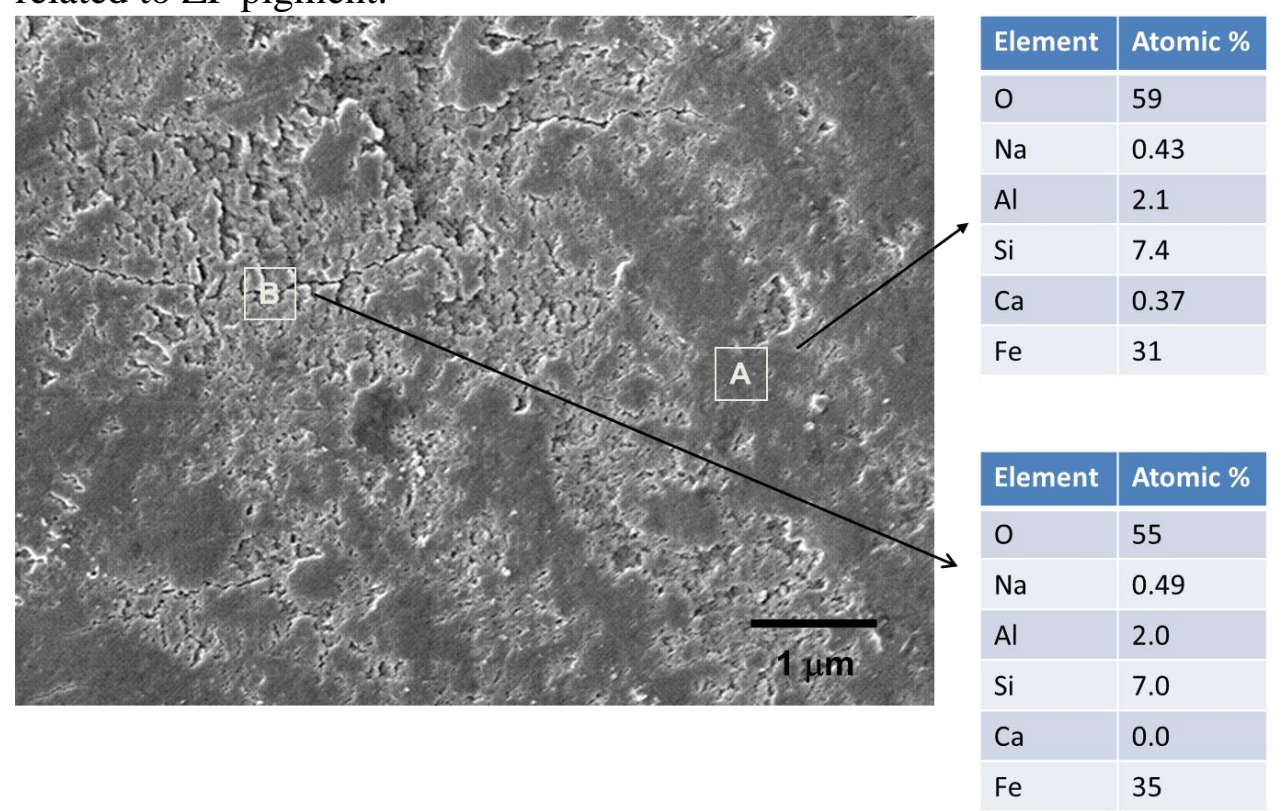

Figure 12. HR-SEM image coupled with EDX elemental analysis for PS/ZP-treated CS surface at $300^{\circ} \mathrm{C}$.

The films were analyzed by XRD for products identification (Figure 13). For the $300^{\circ} \mathrm{C}$ D.I. water-treated CS surface, the XRD pattern revealed the presence of two crystalline phases, $\alpha$-Ferrite $(\alpha-\mathrm{Fe})$ as metal substrate and magnetite $\left(\mathrm{Fe}_{3} \mathrm{O}_{4}\right)$ as passive oxide film formed by the oxidation of CS [30]. When the CS surface was treated with PS solution, a new crystalline phase, analcime $\left(\mathrm{NaAlSi}_{2} \mathrm{O}_{6} \cdot \mathrm{H}_{2} \mathrm{O}\right)$, appeared on the XRD pattern [31] in addition to the $\alpha$-Ferrite and magnetite phases.

This analcime formation is consistent with the results from the HR-SEM and EDX elemental analyses earlier; namely, the cubic-type crystals made of three major elements, $\mathrm{Na}, \mathrm{Al}$, and $\mathrm{Si}$, can be assigned to analcime. This pattern also revealed that additional magnetite was incorporated into the outermost surface layer of CS during treatment with pore solution. In fact, the magnetite-related $d$-spacings gave more intensive signals. Therefore, the analcime layer appeared to be formed as a secondary duplex film over the magnetite passive layer. By contrast, no pronounced $d$-spacing pertinent to analcime was found in the PS/CBS-treated CS. Some weak signals in the " $2 \theta$ " range of 10 to 28.8 degree may be due to the formation of amorphous $\mathrm{Na}_{2} \mathrm{O}-\mathrm{Al}_{2} \mathrm{O}_{3}-\mathrm{SiO}_{2}-\mathrm{H}_{2} \mathrm{O}$ phases. If this interpretation is valid, the ionic species extracted from CBS in PS at $300^{\circ} \mathrm{C}$ restrained the crystallization of $\mathrm{Na}_{2} \mathrm{O}-\mathrm{Al}_{2} \mathrm{O}_{3}-\mathrm{SiO}_{2}-\mathrm{H}_{2} \mathrm{O}$ phase, resulting in a passive film with a 
relatively smooth surface texture. Correspondingly, the reticulate-shaped reaction products formed in both the PS and PS/CBS solutions are more likely to be associated with the formation of amorphous phase rather than a crystalline one. Similarly, the cotton ball-like reaction products observed on the PS/CBS-treated CS's surface were essentially amorphous $\mathrm{Na}_{2} \mathrm{O}-\mathrm{Al}_{2} \mathrm{O}_{3}-\mathrm{SiO}_{2}-\mathrm{H}_{2} \mathrm{O}$. Hence, in this case, this amorphous phase was formed as the duplex passive film.

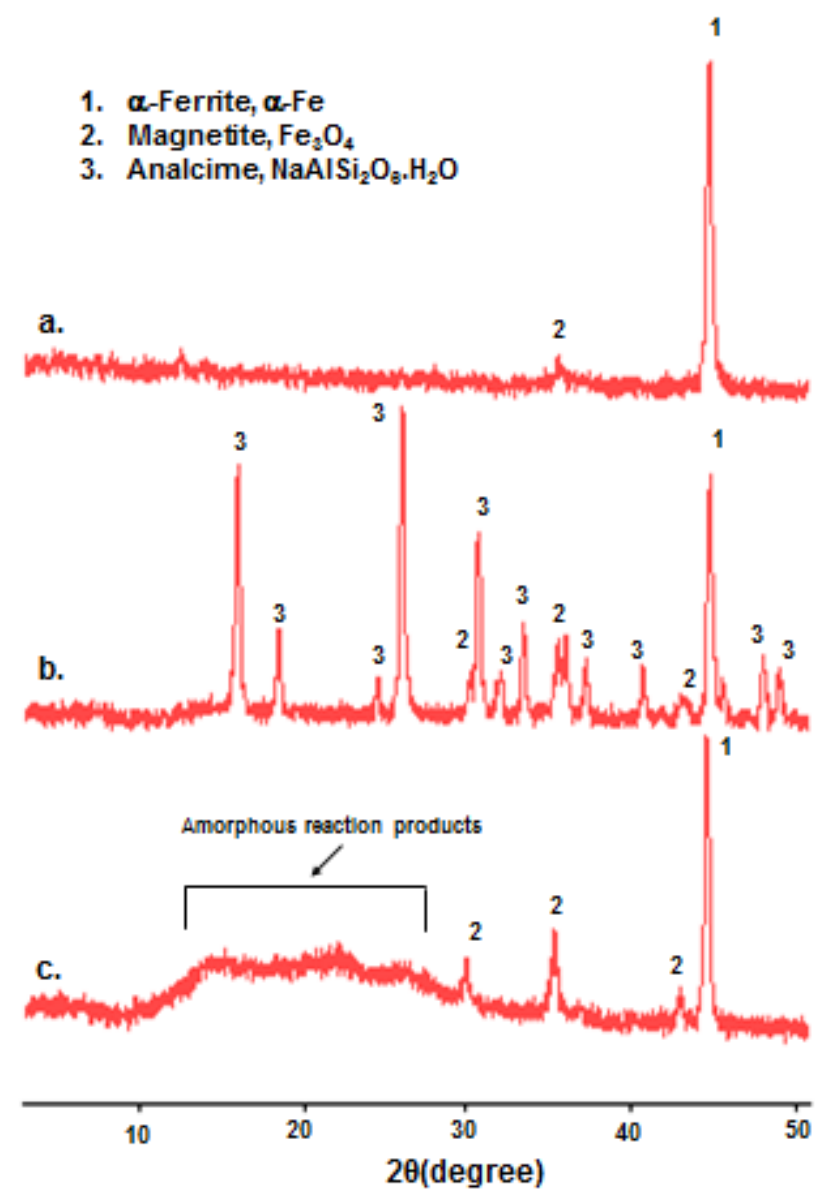

Figure 13. XRD patterns for CS surfaces after 3 days in D.I. water (a), PS (b), and $\mathrm{PS} / \mathrm{CBS}(\mathrm{c})$ at $300^{\circ} \mathrm{C}$.

Figure 14 shows the XRD $d$-spacing pattern for the surfaces of CS treated with PS/CP and PS/ZP at $300^{\circ} \mathrm{C}$. For the PS/CP, as expected, the analcime phase coexists with the $\alpha$ ferrite and magnetite phases. Additionally, goethite, $\alpha-\mathrm{FeOOH}$, phase $[32,33]$ was formed as another Fe oxide on the treated CS surface. Since the EDX spectrum had four major elements, $\mathrm{O}, \mathrm{Al}, \mathrm{Si}$, and $\mathrm{Fe}$, in the wrinkle-shaped reaction product it may be associated with $\mathrm{Al}_{2} \mathrm{O}_{3}-\mathrm{SiO}_{2}-\mathrm{H}_{2} \mathrm{O}$ amorphous phases. Similar to PS/CBS, there was no formation of analcime on PS/ZP-treated CS surfaces, while there were some unknown amorphous reaction products in conjunction with magnetite and $\alpha$-ferrite. According to EDX data the duplex passive film was comprised of two major elements, $\mathrm{Al}$ and $\mathrm{Si}$, and two minor elements, $\mathrm{Na}$ and $\mathrm{Ca}$. Hence, this film seems to be fabricated by amorphous $\mathrm{Al}_{2} \mathrm{O}_{3}-\mathrm{SiO}_{2}-\mathrm{H}_{2} \mathrm{O}$ phase. No ions released by the pigments were detected in the film 
unlike for films reported to form at higher pigment concentrations on metal surfaces [3440].

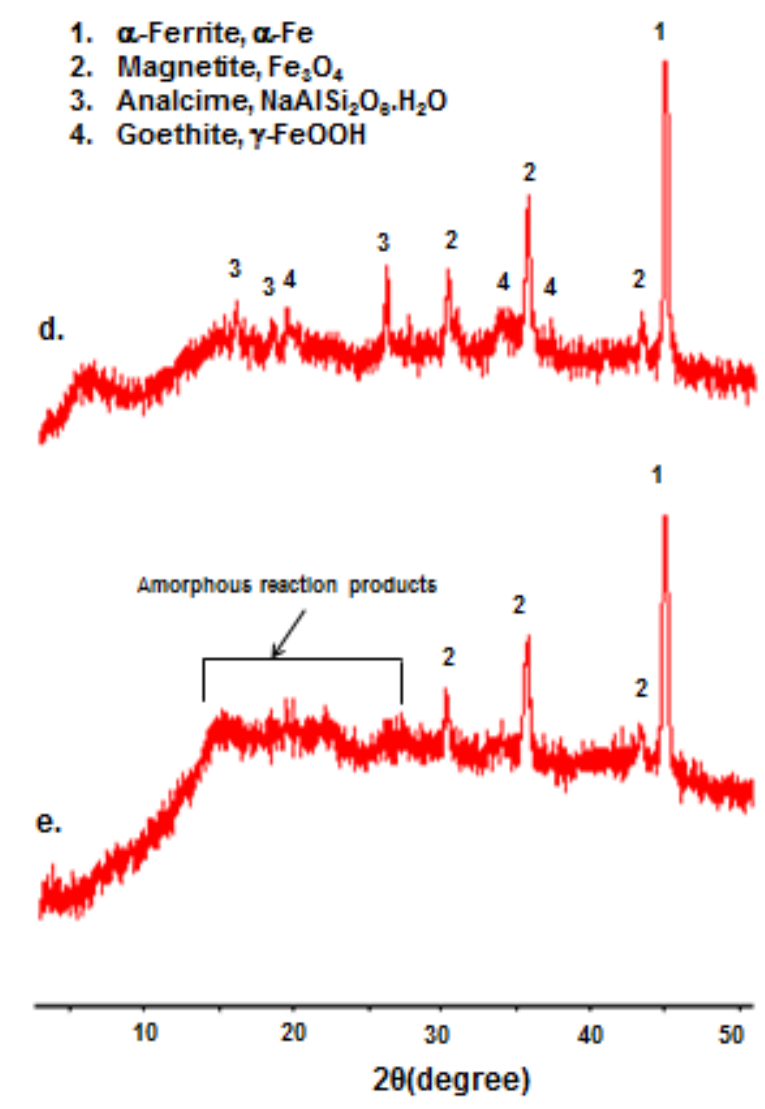

Figure 14. XRD patterns for CS surfaces after 3 days in PS/CP (d) and PS/ZP (e) at $300^{\circ} \mathrm{C}$.

Relating this finding to the corrosion mitigation of CS by passive films, the smooth duplex passive barrier layer constituted of the amorphous $\mathrm{Na}_{2} \mathrm{O}-\mathrm{Al}_{2} \mathrm{O}_{3}-\mathrm{SiO}_{2}-\mathrm{H}_{2} \mathrm{O}$ phase made from PS/CBS displayed a better performance in protecting the CS against the brinecaused corrosion than that of a well crystallized analcime-based rough duplex barrier layer derived from PS alone and PS/CP. The possible reasons for such great performance of the barrier formed in the presence of CBS were: 1) its great adherence to the underlying magnetite passive layer; 2) its extensive coverage of the CS; and, 3) exclusive anodic corrosion protection. On the other hand, similar to the PS/CBS-derived duplex film, a relatively thin duplex film was also fabricated from PS/ZP. However, some areas of this film had porous, dendritic microstructure that may result in a poor coverage of the CS surface and an increased transportation rate of corrosive electrolytes through the film. Thus, the corrosion-mitigating performance of thin PS/CBS-derived film appeared to be better than that of PS/ZP. 
To explain such ineffectiveness of PS/CP- and /ZP-derived duplex passive films, as described in the introduction, several investigators had reported that the solubility of phosphate-based pigments in alkali solution was poor [3, 4, 8, 41]. However, in this limited study, there was no experimental evidence on whether such poor solubility of ZP and CP pigments in PS was the reason for fabricating a poor protective barrier layer.

\section{Conclusions}

To improve the ability of air-foam sodium metasilicate-activated calcium aluminate cement /Class F fly ash blend to protect the carbon steel against brine-caused corrosion at hydrothermal temperatures of $200^{\circ} \mathrm{C}$ and $300^{\circ} \mathrm{C}$, three inorganic pigments, zinc phosphate (ZP), calcium phosphate (CP), and calcium borosilicate (CBS), were evaluated as high-temperature corrosion-inhibitive additives.

The results revealed that adding ZP and CBS pigments to the cement offered the improved corrosion mitigation of carbon steel. Two major factors governed this improvement. One was the densification of hydrated cement during the autoclaving at $300^{\circ} \mathrm{C}$; the other was the inhibition of the anodic reactions at the anodic corrosion site. The densification of the cement resulted in decreased transportation rate of corrosive ions due to the enhanced pore resistance and increased compressive strength as a function of pigment content. The efficiency of corrosion resistance due to the pigments was similar for CBS and ZP; however, CBS displayed a better protection against anodic corrosion than $\mathrm{ZP}$. CP was not as efficient as $\mathrm{CBS}$ and $\mathrm{ZP}$ in reducing corrosion rate. Investigation of the passive films formed by cement slurry pore solution modified with different pigments suggested that the most efficient film formed by CBS pigment had a non-porous structure and consisted of amorphous $\mathrm{Na}_{2} \mathrm{O}-\mathrm{Al}_{2} \mathrm{O}_{3}-\mathrm{SiO}_{2}-\mathrm{H}_{2} \mathrm{O}$ with a smooth surface, good adherence to the magnetite layer on the carbon steel surface and extensive surface coverage. The pore solution without pigments formed passive film with rough surface texture consisting of crystalline analcime phase $\left(\mathrm{NaAlSi}_{2} \mathrm{O}_{6} \cdot \mathrm{H}_{2} \mathrm{O}\right)$ and reticulateshaped amorphous phase $\left(\mathrm{Na}_{2} \mathrm{O}-\mathrm{Al}_{2} \mathrm{O}_{3}-\mathrm{SiO}_{2}-\mathrm{H}_{2} \mathrm{O}\right)$. ZP-modified pore solution formed a smooth amorphous $\mathrm{Al}_{2} \mathrm{O}_{3}-\mathrm{SiO}_{2}-\mathrm{H}_{2} \mathrm{O}$ passive film that was porous with dendritic microstructure allowing an easy permeation of corrosive electrolytes, while CP-modified pore solution produced a rough-surface passive film similar to non-modified pore solution and consisting of analcime and $\mathrm{Al}_{2} \mathrm{O}_{3}-\mathrm{SiO}_{2}-\mathrm{H}_{2} \mathrm{O}$.

Furthermore, the quality of protective barrier films derived from these pigment-modified pore solutions depended on the hydrothermal temperature. The $300^{\circ} \mathrm{C}$-made films displayed a better corrosion protection than those made at $200^{\circ} \mathrm{C}$.

\section{Acknowledgements}

This publication was based on the work supported by Geothermal Technologies Office in DOE Energy Efficiency and Renewable Energy (EERE), under the auspices of the US Department of Energy, Washington, DC, under Contract No. DE-AC02-98CH 10886. The research was carried out in part at the Center for Functional Nanomaterials, Brookhaven National Laboratory, which is supported by the U.S. Department of Energy, Office of Basic Energy Sciences, under Contract No. DE-AC02-98CH10886. 


\section{References}

1. T. Sugama, L. E. Brothers, T. R. Van de Putte, Air-foamed calcium aluminate phosphate cement for geothermal wells, Cem Concr Comp 2005; 27: 758-768.

2. T. Sugama, T. Pyatina, Functional acrylic polymer as corrosion inhibitor of carbons steel in autoclaved air-foamed sodium silicate-activated calcium aluminate/Class F fly ash cement, Engineering 2013; 5: 887-901.

3. M. Bethencourt, F.J. Botana, M. Marcos, R.M. Osuna, J.M. Sanchez-Amaya, Inhibitor properties of "green" pigments for paints. Prog Org Coat 2003; 46: 280287.

4. A. Kalendova, P. Kalenda, D. Vesely, Comparison of the efficiency of inorganic nonmetal pigments with zinc powder in anticorrosion paints. Prog Org Coat 2006; 57: 1-10.

5. P. de Lima-Neto, A.P. de Araujo, W.S. Araujo, A.N. Correia, Study of the anticorrosive behavior of epoxy binders containing non-toxic inorganic corrosion inhibitor pigments. Prog Org Coat 2008; 62: 344-350.

6. B.A. Bhanvas, Y. Kutbuddin, R.N. Borse, N.R. Selokar, D.V. Pinjari, P.R. Gogate, S.H. Sonawane, Ultrasound assisted synthesis of calcium zinc phosphate pigment and its application in nanocontainer of active anticorrosion coatings. Chem Eng J. 2013; 231: 345-354.

7. E. Alibakhshi, E. Ghasemi, M. Mahdavian, Corrosion inhibitor by lithium zinc phosphate pigment. Corros Sci 2013; 77: 222-229.

8. A. Amirudin, C. Barreau, R. Hellouin, D. Thierry, Evaluation of anti-corrosion pigments by extract studies, atmospheric exposure and electrochemical impedance spectroscopy. Prog Org Coat 1995; 25: 339-355.

9. D. El-Hamaid, G. Blustein, M. Deya, B. del Amo, R. Romagnoli, The anticorrosive performance of zinc-free non-toxic pigment for paints. Mater Chem Phys 2011; 127: 353-357.

10. H. Kukackova, A. Vrastilova, A. Kalendova, Non-toxic anticorrosive pigments intended for applications in high-solids and waterborne paints. Physics Procedia 2013; 44: 238-246.

11. R. Naderi, M.M. Attar, Application of the electrochemical noise method to evaluate the effectiveness of modification of zinc phosphate anticorrosion pigment. Corros Sci 2009; 51: 833-840.

12. M. Mahdavian, R. Naderi, Corrosion inhibition of mild steel in sodium chloride solution by some zinc complexes. Corros Sci 2011; 53: 1194-1200.

13. K. Y. Ann, H. S. Jung, H. S. Kim, S. S. Kim, H. Y. Moon, Effect of calcium nitrite-based corrosion inhibitor in preventing corrosion of embedded steel in concrete. Cem Concr Res 2006; 36: 530-35.

14. M. Saremi, E. Mahallati, A study on chloride-induced depassivation of mild steel in simulated concrete pore solution. Cem Concr Res 2002; 32: 1915-21.

15. P. Ghods, O. B. Isgor, G. A. McRae, G. P. Gu, Electrochemical investigation of chloride-induced depassivation of black steel rebar under simulated service conditions. Corros Sci 2010; 52: 1649-59.

16. Y. M. Tang, Y. F. Miao, Y. Zuo, G. D. Zhang, C. L. Wang, Corrosion behavior of steel in simulated concrete pore solutions treated with calcium silicate hydrates. Constr Build Mater 2012; 30: 252-56. 
17. A. R. Boga, I, B, Topcu, Influence of fly ash on corrosion resistance and chloride ion permeability of concrete. Constr Build Mater 2012; 31: 258-64.

18. J. Hu, D. A. Koleva, K. van Breugel, Corrosion performance of reinforced mortar in the presence of polymeric nano-aggregates: electrochemical behavior, surface analysis, and properties of the steel/cement past interface. J. Mater Sci 2012; 47: 4981-95.

19. O. Lahodny-Sarc, L. Kastelan, The influence of $\mathrm{pH}$ on the inhibition of corrosion on iron and mild steel by sodium silicate. Corros Sci 1981; 21: 265-271.

20. S.T. Amaral, I.I. Muller, A RRDE study of the electrochemical behavior of iron in solutions containing silicate and sulphate at $\mathrm{pH}$ 10-13. Corros Sci 1999; 41: 759771.

21. T. Hiemstra, M.O. Barnett, W.H. van Riemsdijk, Interaction of silicic acid with goethite. J. Coll Interf Sci 2007; 310: 8-17.

22. M. Salasi, T. Shahrabi, E. Roayaei, M. Aliofkhazraei, The electrochemical behavior of environment-friendly inhibitors of silicate and phosphonate in corrosion control of carbon steel in soft water media. Mater Chem Phys 2007; 104: 183-190.

23. M-r Yuan, J-t Lu, G. Kong, Effect of $\mathrm{SiO}_{2}: \mathrm{Na}_{2} \mathrm{O}$ molar ratio of sodium silicate on the corrosion resistance of silicate conversion coatings. Surf Coat Tech 2010; 204 : 1229-1235.

24. G.D. Schutter and L. Luo, Effect of corrosion inhibiting admixtures on concrete properties. Constr Build Mater 2004; 18: 483-489.

25. K.Y. Ann, H.S. Jung, H.S. Kim, S.S. Kim, H.Y. Moon, Effect of calcium nitritebased corrosion inhibitor in preventing corrosion of embedded steel in concrete. Cem Concr Res 2006; 36: 530-535.

26. S.M. Alvarez, A. Bautista, F. Velasco, Corrosion behaviour of corrugated lean duplex stainless steels in simulated concrete pore solutions. Corros Sci 2011; 53: 1748-1755.

27. J.K. Singh, D.D.N. Singh, The nature of rusts and corrosion characteristics of low alloy an plain carbon steels in three kinds of concrete pore solution with salinity and different $\mathrm{pH}$. Corros Sci 2012; 56: 129-142.

28. P. Garces, P. Saura, E. Zornoza, C. Andrade, Influence of $\mathrm{pH}$ on the nitrite corrosion inhibition of reinforcing steel in simulated concrete pore solution. Corros Sci 2011; 53: 3991-4000.

29. Y.T. Tan, S.L. Wijesinghe, D.J. Blackwood, The inhibitive effect of bicarbonate and carbonate ions on carbon steel in simulated concrete pore solution. Corros Sci 2014; 88: 152-160.

30. Y. Murayama, T. Satoh, S. Uchida, Y. Satoh, S. Nagata, T. Satoh, Y. Wada, M. Tachibana, Effect of hydrogen peroxide on intergranular stress corrosion cracking of stainless steel in high temperature water, (V). J. Nucl Sci Technol 2002; 39: 1199-1206.

31. International Center for Diffraction Data, JCPDS, Powder Diffraction File Inorganic Phases File No. 19-1180.

32. S. Krehula, S. Music, Z. Skoko, S. Popovic, The influence of Zn-dopant on the precipitation of $\alpha-\mathrm{FeOOH}$ in highly alkaline media. J. Alloy Compd 2006; 420: 260-268. 
33. X. Liu, G. Qiu, A. Yan, Z. Wang, X. Li, Hydrothermal synthesis and characterization of $\alpha-\mathrm{Fe}_{2} \mathrm{O}_{3}$ uniform nanocrystallines. J. Alloy Compd 2007; 433: 216-220.

34. Y. Hao, F. Liu, E.-H. Han, S. Anjum, G. Xu, The mechanism of inhibition by zinc phosphate in an epoxy coating. Corros Sci 2013, 69: 77-86.

35. L. Kouisni, M. Azzi, M. Zertoubi, F. Dalard, Phosphate coatings on magnesium alloy AM60: Part 1: Study of the formation and the growth of zinc phosphate films. Surf Coat Technol 2004; 185: 58-67.

36. L. Kouisni, M. Azzi, F. Dalard, S. Maximovitch, Phosphate coatings on magnesium alloy AM60: Part 2: Electrochemical behavior in borate buffer solution. Surf Coat Technol 2005; 192: 239-246.

37. G.Y. Li, J.S. Lian, L.Y. Niu, Z.H. Jiang, Q. Jiang, Growth of zinc phosphate coatings on AZ91D magnesium alloy. Surf Coat Technol 2006; 201: 1814-1820.

38. H. Y. Su, C.-S. Lin, Effect of additives on the properties of phosphate conversion coating on electrogalvanized steel sheet. Corros Sci 2014; 88: 137-146.

39. R. Amini, A.A. Sarabi, The corrosion properties of phosphate coating on AZ31 magnesium alloy: effect of sodium dodecyl sulfate (SDS) as an eco-friendly accelerating agent. Appl Surf Sci 2011; 257: 7134-7139.

40. G.Y. Li, J.S. Lian, L.Y. Niu, Z.H. Jiang, Influence of $\mathrm{pH}$ of phosphate bath on the zinc phosphate coating on AZ91D magnesium alloy. Adv Eng Mater 2006; 8: $123-127$.

41. E. Alibkhshi, E. Ghasemi, M. Mandavian, Sodium zinc phosphate as a corrosion inhibitive pigment, Prog. Org. Coat. 77 (2014) 1155-1162. 